\title{
XVI. YY. dan Cumhuriyetin İlk Yıllarına Kadar Türk-İran Sınır Sorunları ve Çözümü
}

\author{
Dr. Öğ. Bnb. Efdal AS*
}

\begin{abstract}
$\ddot{O} z e t$
Türkiye-İran sinırı ile ilgili olarak toplumdaki genel kanı, 1639 Kasr-ı Şirin Anlaşması'ndan sonra iki ülke arasında önemli sorunların yaşanmadiğl, dolaylsıly la herhangi bir sıcak çatışma meydana gelmediği ve sinırları bu tarihten günümüze kadar değişmeden kaldı̆̆ şeklindedir. Halbuki Batı'daki mücadeleler kadar olmasa da 1639'dan sonra da Osmanlı ile Iran arasında irili ufakl çekişme ve çatışmalar yaşanmış ve bu durum da sinır konusunda uzun süren anlaşmazllkları beraberinde getirmiştir. Bu makalede, XVI. yy. dan yakın döneme kadar gelen çatısmalar ve sinır sorunları ele alınarak, yukarıda belirtilen genel kanının değişstirilmesine katkı yapılmaya çalışılmaktadır.
\end{abstract}

Anahtar Kelimeler : Iran, sınır, hudut komisyonu, dışişleri, Memduh Şevket Esendal, Hüsrev Gerede

\section{Abstract}

The public opinion in relation to Turkey-Iran border is that the two countries did not experience any major problems after the Kasr-i Sirin Treaty of 1639, so no serious military conflicts occurred between them; and borders remain unchanged from that date until today. In fact, after 1639 in small or large scales conflicts and clashes were experienced between the Ottomans and Iran even if they were not as

\footnotetext{
${ }^{*}$ Kara Harp Okulu Tarih Öğretim Elemanı
} 
serious as those in the Western world. This article will try to contribute to the efforts to change the above mentioned public opinion by dealing with the conflicts and border disputes from the XVI. century until recent times.

Key Words : Iran, border, boundary commission, foreign affairs, Memduh Şevket Esendal, Hüsrev Gerede

\section{Giriş}

Ön Asya'nın iki önemli coğrafi bölgesi olan Anadolu ve İran, İlkçağlardan günümüze kadar birçok uygarlığa ev sahipliği yapmıştır. Kimi zaman bu uygarlıklardan bazıları tek başına her iki bölgeye sahip olurken, kimi zaman da her iki bölgede farklı uygarlıklar hüküm sürmüş ve bu uygarlıklar arasında, Dünya Tarihi açısından dönüm noktası sayılabilecek hakimiyet mücadeleleri meydana gelmiştir. Lidya - Pers, İyon - Pers, Roma - Sasani, Bizans - Sasani, Bizans - Selçuklu, Anadolu Selçukluları - İlhanlı, Osmanl - Timurlu, Osmanl - Akkoyunlu ve son olarak da Osmanlı Safevi mücadeleleri, söz konusu coğrafyanın en önemli mücadelelerini oluşturmaktadır. Bu makalenin konusunu oluşturan sınır sorunları, yukarıda zikredilen son mücadelenin siyasal, ekonomik ve dinsel/mezhepsel yansımasıdır denilebilir.

14. yy.ın başlarında bir uç beyliği olarak kurulan, gazâ ve cihad politikasının bir sonucu olarak öncelikli hedefi olan Balkanlar'1 ele geçiren, önce bağımsız bir devlete, 16. yy.ın başlarından itibaren de bir imparatorluğa dönüşmeye başlayan Osmanlılar, hemen hemen aynı dönemde doğuda belirmeye başlayan ve etnik açıdan kendi kurucularıyla aynı ırksal kökene sahip bulunan bir siyasal/dinsel liderin sürüklediği güçle karşılaşmak durumunda kalmışlardır. Bu karşılaşma, Dört Halife Devri'nin son dönemindeki Hz. Ali - Muaviye ve sonrasındaki Hz. Hasan - Muaviye, Hz. Hüseyin - Yezid mücadelelerinin başlatmış olduğu Sünnî - Şî̂ rekabetini, teolojik boyuttan siyasal boyuta yönlendirmiştir.

Hazar Denizi'nin güneydoğusunda bulunan Erdebil Eyaletinin aynı adlı merkezinde doğup, İslam dinine farklı bir yorum getirerek taraftar toplayan Ebu'l Safiyyüddin İshak1 Erdebili (1252- 1334) ya da bilinen adiya Şeyh Safi'nin dinsel öğretileri ${ }^{2}$, beşinci kuşaktan torunu Şeyh Cüneyd döneminde

\footnotetext{
${ }^{1}$ Ahmet Yaşar Ocak, "Osmanlı Kaynaklarında ve ModernTürk Tarihçiliğinde OsmanlıSafevî Münasebetleri (XVI-XVII. Yüzyıllar)”, Belleten, C:LXVI, (Ağustos 2002), S:246'dan ayribasım, TTK Basımevi, Ankara, 2003, s. 503

${ }^{2}$ Abbaslı'ya göre bu öğreti, diğer din ve mezheplere taasupsuz olarak yaklaşmakta ve Şeyh Safi, tasavvufi ve felsefi sorunların çözümünde Hz. Muhammed'e dayandığı gibi yeri geldikçe Hz. İsa'ya da dayanmaktadır. Bu da birçok Budist, Hristiyan ve diğer mezhep
} 
(dinsel liderliği 1449-1456) Doğu Anadolu, Azerbaycan ve İran bölgelerinde gittikçe yaygın hâle gelmiştir.

Kazandığ 1 bu dinsel çekim gücünü siyasal bir yapıya dönüştürmek isteyen Şeyh Cüneyd, her ne kadar bir devlet kurmayı başaramasa da dönemin Akkoyunlu hükümdarı Uzun Hasan'ın kız kardeşi Hatice Begim ile evlenerek, geleceğe yönelik güçlü bir örgütlenmenin temellerini atmıştır. Nitekim Şeyh Cüneyd, diğer eşlerinden yetişkin oğulları varken, Hatice Begim'den olan çocuk yaştaki Haydar'1, Erdebil postunun varisi ilan etmiştir ${ }^{3}$. Şeyh Haydar, babasının izinden giderek dayısı Uzun Hasan'ın kızı Halime Begim ile evlenmiş ve böylece güçlü bir hanedanla olan sıhri bağlarını pekiştirmiştir. Bu evlilikten, aralarında Safevi Devleti'nin kurucusu İsmail'in de bulunduğu üç oğlu dünyaya gelmiştir.

Öncelikli hedefi Anadolu'daki teşkilatı geliştirmek ve müridlerinin sayısını artırmak olan Şeyh Haydar, bu hedefinde başarılı olmuş ve Anadolu'daki tarikat mensupları hızla çoğalmaya başlamıştır. Öyle ki, Anadolu'daki tarikat mensupları, İran'da bulunanların sayısını geçmiş ve tarikat, başı Azerbaycan'daki Erdebil'de, gövdesi de Anadolu'da olan bir yapıya bürünmüştür. ${ }^{4}$

Şeyh Haydar'ın Şirvan seferi sırasındaki mücadelelerden birinde 1488 'de öldürülmesiyle yerine büyük oğlu Ali geçtiyse de Akkoyunlu taht mücadeleleri sırasında 1493 'te o da babasının akıbetine uğramıştır. Akoyunlu hanedanının, Haydar'ın diğer iki oğlu olan İsmail ve İbrahim'e zarar vermesinde çekinen tarikat üyeleri, onları altı yıl kadar çeşitli şehirlerde saklamışlardır. 1500 yılında Anadolu'ya gelip Erzincan bölgesinde ikamet etmeye başlayan İsmail'e, Anadolu'nun Türkmen

sahiplerinin Safefiyye akımına bağlanmasına neden olmaktadır. Bkz. Mirza Abbaslı, "Safevilerin Kökenine Dair", Belleten, C:XL, (Nisan 1976), S:158'den ayrıbasım, TTK Basımevi, Ankara, 1976, s. 299-300.

${ }^{3}$ Faruk Sümer, Safevi Devletinin Kuruluşu ve Gelişmesinde Anadolu Türkleri’nin Rolü, TTK Basımevi, Ankara, 1992, s.11.

${ }^{4}$ Sümer, a.g.e., s. 12. Sümer, tarikatın Anadolu'da yaygınlaşmasında, Haydar'ın sayısı gittikçe artan müridlerinin karışıklık çıkarmalarından çekinen II.Bayezid'in gevşek yönetiminin önemli bir rol oynadığını belirtmektedir. Ocak ise II.Bayezid'in Safeviler'e karşı ilgisiz olduğu suçlamasının bütünüyle doğru olmadığını, 1501 tarihli bir ahkâm defterine dayanarak belirtmektedir. Buna göre defter, Osmanlı topraklarından "yukaru canib” denilen İran'a sığınmak isteyen Erdebil tekkesine bağlı silahlı sûfilerin yakalanıp siyaseten katl edilmelerini, buna karşılık oradan da Osmanlı topraklarına sığınmak isteyenlere izin verilmemesini buyuran hükümlerden oluşmaktadır. (Ocak, a.g.m., s. 506). 
kitlelerinden (Ustacalu, Şamlu, Rumlu, Tekelü, Dulkadir, Karamanlı, Afşar, Kaçar, Karadağlu ve Varsak Türkleri) büyük katılımlar olmuştur 5 .

Kalabalık Türkmen gruplarıla birlikte 1501 başlarında Erzincan'dan ayrılan İsmail, önce Şirvan'ı alarak babasının hedefini gerçekleştirmiş, daha sonra da Akkoyunlu Elvend'i aynı yılın yaz ayında Nahçıvan bölgesinde yapılan Şurur Savaşı'nda yenilgiye uğratmıştır. Böylece Azerbaycan'ın kuzey toprakları (Şirvan, Karabağ, Nahçıvan) ile güney topraklarını (Tebriz, Meraga, Erdebil, Talış) ele geçirmiş, Tebriz'de şahlık tahtına oturup, "12 İmam" adına hutbe okutarak Safeviler Devleti'ni resmen kurmuştur.

Görüldüğü gibi Safevi Devleti, hem kurucusunun Erdebil kökenli bir aileden gelmesi dolayısıyla, hem de Anadolu'dan gelen ve zamanla bölgeye yerleşen Türkmenler'in katkıları nedeniyle, bazı tarihçilerin görüşlerinin aksine bir Türk devleti karakteri taşımaktadır ${ }^{6}$.

Artık şah olan İsmail, önceleri dönemin Osmanlı padişahı II.Bayezid ile iyi ilişkiler içerisinde olmaya özen göstermiştir. Öyle ki, karş1lıklı mektuplaşmalarda II.Bayezid'e hitabı "baba" şeklinde olmuştur?". Bu dönemde iki ülke arasındaki temel sorun, Safevi topraklarına yani İsmail'in hükümdarlık bölgesine göç eden Anadolulu müridlerdir. Fakat sorunun henüz siyasal ve dinsel boyutu yoktur. Osmanlı açısından sorun ekonomiktir. Çünkü devlet hizmetinde bulunanlara tahsis edilmiş olan ve bu hizmetlilerin geçimlerini sağlayan vergiler, söz konusu göç eden kitleler üzerinden alınmaktadır. Dolayısıyla arkası kesilmeyen göçler, hizmet erbabı denilen kitleleri zarara uğratmaktadır. II.Bayezid, almış olduğu askerî önlemlerle bu göçleri engellemeye çalışmıştır. Burada şunu da belirtmemiz gerekir ki bu göçlerde, söz konusu vergilerin halkta yaratmış olduğu hoşnutsuzluk da önemli bir etkendir.

Şah İsmail'in Osmanlı Devleti'ne karşı tutum değişikliğinin kırılma noktalarından birisi, 1510 yılında Özbek Şeybaniler'e karşı kazanmış olduğu zaferdir. Çünkü bu zafer, Horasan bölgesinin katılımıyla ülke topraklarını

${ }^{5}$ Oktay Efendizade, Safevi Devleti’nin Kuruluşunda Azeri Türklerinin Rolüne Dair, XI. Türk Tarih Kongresi'nden ayribasım, TTK Yayınevi , Ankara, 1994, s. 817

${ }^{6} \mathrm{Bu}$ konuda Hinz, Akkoyunlu Devleti'nin başkentinin Diyarbakır'dan Tebriz'e geçirilmesiyle devletin İranlaşmasının başladı̆̆ını, İran millî devletinin yani Sefevi Devleti'nin kuruluşuna zemin hazırlandığını belirtirken ( Walter Hinz, Uzun Hasan ve Şeyh Cüneyd XV. Yüzyılda İran'ın Millî Bir Devlet Haline Yükselişi,TTK Yay. Ankara, 1992, s.56) ; Ahmed Kesrevi Tebrizî, hanedanın atası Şeyh Safi'nin Türk değil İran etnik unsuruna mensup olduğunu iddia etmiştir. (Bkz. Efendizade, a.g.e., s.814) Abbaslı ise 1357 yılında yazımının tamamlandığını söylediği "Safvetü's-safâ" adlı eserde Şeyh Safi için "Pir-i Türk" dendiğini belirterek, kökenin Azeri Türkleri’ne dayandığını söyler. (Abbaslı, a.g.m., s.329)

${ }^{7}$ Sümer, a.g.e., s. 26 
Fırat'tan Ceyhun'a kadar uzatmıştır. Artık Şah İsmail, daha büyük hedefler peşindedir ve bu hedefe ulaşmada yavaş yavaş dinsel boyut da devreye sokulacaktır. Bu da 1512'de Osmanlı tahtına çıan Yavuz döneminde ilişkilerin gerilmesine neden olacaktır.

$\mathrm{Bu}$ konudaki ilk faaliyet, "halife" denilen misyonerler aracılığıyla yapılan mezhepsel propaganda faaliyetleridir. Bu kişiler, aynı zamanda Şah İsmail adına bağış toplayarak İran'a yollamışlardır. Bu faaliyetler karşısında Osmanlı Devleti, Kızılbaşlık propagandalarının yoğun olarak yapıldığg Orta, Güney ve Doğu Anadolu bölgelerinde sıkı teftişler yaptırarak, Safeviler adına çalışanları ve "halifeler"i yakalatıp idam ettirmiş; İran'dan gelen propaganda kitaplarını yaktırmış, Kızılbaş olup İran'a geçen veya kaçan sipahi sipahi, kale dizdarı vb. yöneticileri tekrar kazanmaya çalışarak bunlardan casus olarak yararlanmaya çalışmıştır.

Sonunda iki ülke arasındaki beklenen çatışma 1514 yılında Çaldıran'da meydana gelmiş, Osmanlı Devleti'nin galibiyetiyle biten savaş bir son değil, Şiî kutsal merkezleri ele geçirmek isteyen Şiî İran devletlerine karşı Sünni dünyanın liderliğini üstlenen Osmanlı'nın bölgeyi prestij için elinde tutma girişimlerini sürdürdüğ̈̈ bir mücadelenin başlangıcı olması yanında, özellikle her iki tarafta bulunan ve yerleşik olmayan aşiretlerin kararsız tutumlarından kaynaklanan asayişsizlikler nedeniyle de uzun yıllar çözülemeyecek sınır sorunlarının oluşmasına ortam hazırlamıştır.

İki ülke mücadelelerinde son olarak ticaret yolları faktörünü de belirtmek yerinde olacaktır. Osmanlı-Safevi arasındaki en çetin mücadelelerin genel olarak Erzurum-Tebriz arasında ve Musul-Bağdat bölgesinde yoğunlaşmasına dikat çeken Kevserani, bu bölgelerin hem İstanbul'a ve denize ulaşan ana yollar olduğu hem de Anadolu'ya gelen fetihlerin ana girişleriolduğu saptamasını yapmıştır ${ }^{8}$

Osmanlı Devleti ile İran arasındaki sınır tespit çalıșmaları, Yavuz Sultan Selim, Kanunî Sultan Süleyman ve II. Selim dönemlerine kadar gitmektedir. Bu üç padişahın tahtta kaldığ 1 dönemden sonra aktedilmiş olan sulh ve sınır tahdidi antlaşmaları hep o eski sınırlara dayanılarak yapılmış ve dönemine göre birtakım değişikliklere uğramıştır.

İran ile Yavuz Sultan Selim ve Şah İsmail döneminden cumhuriyetin ilk yıllarına kadar sınırların kesin çizgilerle tespit edilememiş olması, birçok anlaşmazlık ve çatışmanın da bu yüzden çıkmış olması dikkat çekicidir. 1501-1749 arası dönemde İran'ın Osmanlı Devleti'ne 61 elçi göndermiş olması ve bu elçilerin sadece 10 adedinin sultan cüluslarını kutlamak için

\footnotetext{
${ }^{8}$ Vecih KEVSERANİ, Osmanlı ve Safevilerde Din - Devlet İlişkisi, Denge Yay.,
} İstanbul 1992, s. 75 
gönderilmiş olması ${ }^{9}$, iki ülke arasındaki mücadelelerin ne kadar yoğun olduğunu göstermesi bakımından önemlidir. Türkiye Cumhuriyeti ile İran arasındaki sınırlar, Lozan Antlaşması ile çizilmemiş, iki devletin kendi aralarında imzalamış olduğu ayrı ayrı antlaşmalarla tespit edilmiştir. İran ile Türkiye arasındaki "sınır rejimi" Devletlerarası Hukuku bakımından da ilgi ile incelenecek esaslara dayanmaktadır.

\section{Osmanlı Dönemi}

Osmanlı Devleti'nin sınırlarının Fatih döneminden sonra İran sınırlarına dayanması, İslam dünyasının iki farklı ve güçlü mezhebini karşı karşıya getirmiştir. Yavuz döneminde Osmanl-Safevi İran ilişkileri, söz konusu mezhep çatışmaları ile paralel bir seyir izlemiştir. Safevi hükümdarı Şah İsmail'in kışkırtmaları sonucunda Anadolu'da Şiiliğin yayılmaya başladığını gören Yavuz, bu durumu bir tehdit olarak görmüş ve 1514'te ünlü Çaldıran Seferi'ne çıkmıştır. İran Ordusu'nu yenilgiye uğratan Yavuz, Tebriz'e kadar ilerlemiş, bir süre sonra Anadolu'ya dönmüştür. Padişahın Amasya'da bulunduğu sırada, Şah İsmail tarafından barış yapılması amacıyla bir elçi gönderildiyse de İran seferini sürdürmek isteyen padişah, bu isteğe yanıt vermemiş ve elçiyi nezaret altına aldırmışıır. ${ }^{10}$

Yavuz'dan sonra tahta geçen Kanunî döneminde, Osmanlılar ile Safeviler arasında ilk kez bir barıș anlaşması imzalandığı görülmektedir. Kanuni'nin, hükümdarlığının ilk yıllarında kendisine hedef olarak Batı'yı seçmiş olmasından ve Osmanlı ordusunun Avrupa içlerinde bulunmasından yararlanmak isteyen Safeviler, Anadolu'ya akınlar düzenlemeye başlamışlardır.

Doğu sınırlarındaki saldırılara önlem almak isteyen Kanuni, Macar seferinden dönüşünde Rüstem Paşa'yı İran'a seferle görevlendirdiyse de Şehzade Mustafa Olayı'nın meydana gelmesiyle Rüstem Paşa'yı geri çağırmıştır. Sonraki dönemde ise bu kez 1553 Yazı'nda, bizzat ordusunun başında İran seferine çıkan Kanuni, Erzurum'da bulunduğu sırada, dönemin İran hükümdarı Şah Tahmasb'ın barış elçisi göndererek mütareke istemesi üzerine Eylül 1554 'te ordusuyla birikte geri dönmüş, kışı Amasya'da geçirmiştir.

\footnotetext{
${ }^{9}$ Orhan Koloğlu, “Osmanlı’nın İran İlişkileri”, Popüler Tarih, (Mayıs 2005), S.57, s. 71.

${ }^{10}$ İsmail Hakkı Uzunçarşıll, Osmanlı Tarihi, TTK yay., Ankara, 1983, C.II, s. 270 (Yavuz İstanbul'a döndükten bir süre sonra Şah İsmail tarfından iki elçi daha gönderilmişse de bu iki elçi de önceki elçinin akıbetine uğramıştır. Hoca Saadettin, Tacü’t Tevarih, C.II, s. 323)
} 
Padişahın Amasya'da bulunduğu dönemde buraya gelen İran elçileriyle barıș görüșmeleri yapılmıș ve sonuçta 37 yıldır aralıklarla süren savașlara son verilmiş, 29 Mayıs 1555 'te (8 Recep 962) Amasya Muahedenamesi akdedilmiştir. ${ }^{11}$ Buna göre, Azerbaycan ile merkezi olan Tebriz, Doğu Anadolu ve Irak-1 Arap, Osmanlı Devleti'ne bırakılmıştır. İran ile yapılmış olan bu ilk barıș anlaşması, II.Selim döneminde, 1568 yılında aynı esaslar üzerinden yenilenmiştir. Anlaşma, Şah Tahmasb'ın öldüğü ve İran'da karışıklıkların çıktığı 1576 yılına kadar sürmüştür. ${ }^{12}$

III.Murad döneminde, 1577 yılında Lala Mustafa Paşa tarafindan İran üzerine başlatılan seferler aralıklı olarak 1589'a kadar sürmüş, sonuçta 21 Mart 1590'da Ferhat Paşa Antlaşması imzalanmıştır. Anlaşmaya göre İran; Tebriz'i, Azerbaycan'ın Tebriz'e tâbi parçasını, Karabağ, Şirvan, Loristan, Gürcistan ve Şehrizor (Kerkük)'u Osmanlılar'a vermiștir.'

İki ülke arasındaki barış çok uzun sürmemiş, I. Ahmed döneminde, 1603 yılında İran ile savaşlar tekrar başlamıştır. 1612 yılına gelindiğinde, Kuyucu Murad Paşa'nın yerine veziriazam olan Nasuh Paşa'nın, Şah Abbas'ın barış yapma isteğini kabul etmesiyle 1613'te İstanbul'da Nasuh Paşa Antlaşması adıyla yeni bir barış antlaşması imzalanmıştır. Bu anlaşma ile sınırlar, III. Murat ve III. Mehmet zamanındaki şekline sokulmuştur. Ayrıca Şah; Tebriz, Revan ve Şirvan'ın vergisi olarak her yıl iki yüz yük ipek vermeyi kabul etmiştir. ${ }^{14}$

II. Osman döneminde, İran'ın Nasuh Paşa Anlaşması'ndaki yükümlülüklerini yerine getirmemesi nedeniyle $1615^{\prime}$ te iki ülke arasında tekrar başlayan savaşın sonunda, Serav ovasında, Sadrazam Halil Paşa ile Şah Abbas'ın murahhas Elçisi Burun Kasım arasında, Nasuh Paşa Andlaşması esasları dahilinde yeni bir barış andlaşması imzalanmıştır (26 Eylül 1618 - Şevval 1027). ${ }^{15}$ Bu anlaşmayı, bir yıl sonra Bağdat ve Ahısha taraflarında hudut düzenlemesine yönelik yapılmış olan bir anlaşma izlemiştir.

IV. Murad zamanında, Bekir Subaşı'nın ve oğlu Mehmet'in ihaneti üzerine Bağdat, Şah Abbas'ın eline geçmiştir. Diğer taraftan Erzurum Beylerbeyi Abaza Paşa da isyan ederek İranlılar'dan yardım istemiştir.

\footnotetext{
${ }^{11}$ Uzunçarşıll, a.g.e., s.361

${ }^{12}$ Joseph V. Hammer, Osmanlı Tarihi, C.II, II.Baskı, İstanbul, 2005, s. 24

${ }^{13}$ A.g.e., s. 195

${ }^{14}$ Mustafa Nuri Paşa, Netayic Ül-Vukuat - Kurumları ve Örgütleriyle Osmanlı Çev: Neşet Çağatay, Ankara, 1992, s. 210

${ }^{15}$ Uzunçarşılı, Osmanlı Tarihi, TTK yay., Ankara, 1983, C.III, 1.kısım, s. 67
} Tarihi, TTK yay., 
Sadrazam Hüsrev Paşa, doğu seferine çıkarak Abaza isyanını bastırmış fakat Bağdat'1 alamamıştır.

Bunun üzerine IV. Murad bizzat sefere çıkmış, önce Revan'1, sonra da Bağdat'1 almıştır. O dönemde İran tahtında oturan ve Şah Abbas'ın torunu olan Şah Şafi'nin barış istemesi üzerine, kendisi rahatsızlığı dolayısıyla İstanbul'a dönmüş, Sadrazam Kara Mustafa Paşa barış antlaşmasını imzalamıștır (1639). Kasr-ı Şirin Antlașması adıyla anılan bu antlașmanın sınırlar hakkındaki hükümlerine göre; Bağdat tarafindan sınır, "Bedre Hassan, Hanikin, Mendeli, Derne ve Dertenk'ten Sermemel bölgesine kadar arada olan yerler" olarak belirlenmiştir. Ayrıca, Zincir Kalesi'nin batısındaki köyler ve Șehrizor yakınındaki Zalim Ali Kalesi çevresi Osmanlı Devleti'nde kalacaktır. Diğer taraftan İran, kuzey sınırındaki Kars, Ahısha, Van ile Şehrizor, Bağdat ve Basra sınırlarına kesinlikle taarruz etmemeyi taahhüt etmiştir. ${ }^{16}$ Böylece, iki ülkenin 1623-1639 yılları arasındaki savaşları da son bulmuştur.

Kasr-1 Şirin Antlaşması'nın ardında Osmanlı İran ilişkilerinde uzun süreli bir barış dönemine girilmiştir. 18.yy.ın ilk yarısında İran içerisinde başlayan karışıklıklar sonucunda Kafkasya'daki sünni kabilelerin, Safevi hanedanından Şah Hüseyin'e isyan etmeleri ve Osmanlı Devleti'nden yardım istemeleri sonucunda, III.Ahmed yönetimindeki Osmanlı Devleti, zaten kendisine sı̆̆ınmış olan Dağıstan, Şirvan, Gürcistan'a ek olarak Van Valisi Köprülüzade Abdullah Paşa kumandasındaki kuvvetlerle Kirmanşah, Ardalan ve Hoy çevresini 1723 yılında kolaylıkla istila etmiştir. ${ }^{17}$

Bu sırada İran'daki karışıklıklardan yararlanmak isteyen Ruslar da Dağıstan, Derbent, Bakü Kalelerini zaptetmişlerdir. Tehlikeyi gören ve Rusya'yı Hazar bölgesinden uzaklaştırmak isteyen Osmanlı Devleti, 1724 yılında Rusya ile bir paylaşım anlaşması imzalamıştır. Bu anlaşmaya göre, Kur ve Aras nehirlerinin birleștiği yerden kuzeye doğru Hazar sahilleri Rusya'da kalacak, Şirvan Hanı Şimahi'de ikamet edecek ve İran'ın batı eyaletleri Osmanlı Devleti'ne verilecektir. ${ }^{18}$

Bu paylaşımda Osmanlı Devleti'nin payına düşen kısımları elde etmek amacıyla askerî harekâta başlanmıştır. Osmanlı Devleti, harekât sonucu yapmış olduğu anlaşmada o dönemde İran tahtını ele geçiren Efganlılar Aşireti reisi Eşref Şah'1 İran şahı olarak tanımış; Kirmanşah, Hemedan, Memleket-i Sitte, Ardalan, Nihavend, Azmâbad, Loristan, Mekri, Mereza,

${ }^{16}$ Anlaşmanın tam metni için bkz: Muahedat Mecmuası, TTK yay., Ankara, 2008, C.II, s. 308-312.

${ }^{17}$ Nihat Erim, "Türkiye Cumhuriyeti'nin Kuzeydoğu ve Doğu Sınırları", Ankara Üniversitesi Hukuk Fakültesi Mecmuası, Y11:1952, C.9, S.1-2, s.15.

${ }^{18}$ A.g.m., s. 15-16. 
Hoy, Serkân, Tebriz, Dilaviz, Gence, Karabăg, Revan, Ardübad, Nahçıvan, Tiflis, Şimaği ve Şirvan'ı topraklarına katmıştır. ${ }^{19}$ Her iki ülke de değişen sınırların tam olarak tespiti için görevlendirmelerde bulunmuştur. ${ }^{20}$

Bağdat Valisi ve Şark Seraskeri Ahmet Paşa tarafindan 4 Ekim 1727'de yapılan bu barış anlaşması uzun süreli olamamış ve Ahmed Paşa yeniden harekâta girişmiştir. Hemedan, Kirmanşah, Ardalan, Urmiye ve Tebriz yeniden Osmanlı Devleti tarafindan ele geçirilince, II. Şah Tahmasb (17221732) barış istemiştir. 1731'de yapılan anlaşmaya göre Hemedan ve Tebriz eyaletleri Şah'a iade edilmiş, Revan ve Şirvan Osmanlı Devletinde kalmıştır.

Galip bir devlet için olumsuz sayılabilecek olan bu anlaşmayı Babıali'nin hoş karşılamaması ve İran'ın da kısa bir süre sonra Bağdat'ı kuşatması üzerine barış bozulmuş, İran kuvvetleri üzerine gönderilen birlikler önce İran kuvvetlerini 1733'te yenilgiye uğrattılarsa da 1735 'e kadar süren mücadeleler sonucunda başarılı olunamamıştır. ${ }^{21}$ I. Mahmud döneminde 1736 yılında İstanbul'da yapılan barış anlaşmasına göre sınırların IV. Murad dönemindeki gibi kalması kararlaştırılmıştır. ${ }^{22}$

1743'te Nadir Şah döneminde Caferi mezhebinin beşinci ehl-i sünnet mezhebi olarak benimsenmesi hakkında Osmanlı Devleti'ne bir öneri yapılmış, önerinin reddedilmesi üzerine de İran, Irak'a tekrar saldırmıştır. ${ }^{23}$ Üç yıl süren çarpışmalar sırasında İran'da çıkan karışıklıklar üzerine Nadir Şah, Caferiye mezhebiyle ilgili önerisini geri aldığını ve barış yapmak istediğini, Fatihali Türkman adlı elçisini İstanbul'a göndermek vasıtasıly bildirmiştir. Sonuçta 1746 'da, iki ülke arasında -1639 sonrası gibi- uzun bir barış döneminin yaşanmasını sağlayan bir anlaşma, Kasr-1 Şirin Anlaşması esasları dahilinde imzalanmış ve yine sınırların IV. Murad dönemindeki gibi kalması kararlaştırılmıştır. ${ }^{24}$

$\mathrm{Bu}$ uzun barış döneminden sonra İranlılar, Yunan İsyanı'ndan yararlanmak istemişler ve sınırın her iki tarafındaki aşiretler aracılığıyla önce karışıklıklar çıkarmışlar, sonra da ileri harekâtla Bayezid ve Bitlis'i ele geçirmişlerdir. Fakat İran ordusunda başlayan kolera salgını, İran'1 barışa

19 A.g.m., s. 16.

${ }^{20}$ Muahedat Mecmuası, s. 314-315.

${ }^{21}$ Abdurrahman Şeref, Tarih-i Devlet-i Osmaniyye, C.II, s. 166

${ }^{22}$ Muahedat Mecmuası, s. 317

${ }^{23}$ Koloğlu, a.g.m., s. 71.

24 Abdurrahman Şeref, a.g.e., s. 176 Abdurrahman Şeref burada “(...) Üç sene kadar imtidad eden bu sefer Iran ile vâki olan muharebatımızın sonudur. Çünkü her iki tarafça dahi vâki olacak kurup ve mukavelâtın beyhude şefk-i dem ve izae-i mal ve kuvvetten başka bir şeyi müntec olmayacağına kanaat hasıl olmuştur (...)” dese de Yunan İsyanı sırasında İran, Osmanlı Devleti'ne karşı tekrar hareketlenecektir. 
zorlamış ve 28 Temmuz 1823 tarihinde, 1746 anlaşması (dolayısıyla 1639 Kasr-1 Şirin Anlaşması) esasları üzerinde anlaşma yapılmıştır. ${ }^{25}$

1838'de bu kez Herat'1 ele geçirmeye çalışan İran'a karşı Bağdat Valisi Ali Rıza Paşa harekete geçmiş ve İran'ın Huzistan eyaletine girmiştir. İran da Osmanlı Devleti toprağı olan Süleymaniye bölgesi ile ilgilenmeye başlamış, böylece iki ülke 1842 yılında savaşın eşiğine gelmişlerdir. Özellikle Rusya ve İngiltere, İran üzerindeki emelleri dolayısıyla konuyla ilgilenmişler ve hem olası bir savaşın önlenebilmesi hem de sınırın kesin olarak tespit edilmesi için Osmanlı Hükûmeti'ne baskı yapmışlardır. ${ }^{26} \mathrm{Bu}$ baskı sonucunda, 15 Mayıs 1843 tarihinde Erzurum'da İngiliz ve Rus temsilcilerinin de arabulucu olarak katılımıyla bir konferans toplanmıştır. Konferansta Osmanlı heyetinin başkanlığını Nuri Efendi (Konferans başlarında ani ölümüyle Enveri Efendi), İran heyetinin başkanlığını Mirza Taki $\operatorname{Han}^{27}$, Rus heyeti başkanlığını Albay Dainese, İngiltere heyet başkanlığını da Albay Williams da yapmışlardır. Ayrıca İngiliz heyetinde, İlk Türkçe İngilizce sözlüğü hazırlamış olan Redhouse da tercüman olarak bulunmuştur. ${ }^{28}$ Çok uzun bir döneme yayılan konferans görüşmeleri sonucunda İngiliz ve Rus temsilciler bir anlaşma taslağı hazırlayarak Osmanlı ve İran temsilcilerine dikte etmişlerdir. ${ }^{29}$ Taraflarla yapılan müzakereler sonucunda 1 Haziran 1847 'de (16 Cemaziyelâhir 1263) Erzurum Anlaşması imzalanmış ve 25 Haziran'da Padişah Adülmecid tarafindan onaylanmıştır. İkinci, üçüncü ve sekizinci maddeleri sınırlarla ilgili $\operatorname{olan}^{30}$ anlaşmanın üçüncü maddesi gereğince, dört ülkenin

${ }^{25}$ Cevdet Paşa, Tarih-i Cevdet, T.C. Kültür Bakanlığı Yayınları, Ankara, 1979, C.II, s. 77-78 ; Muahedat Mecmuası, C. III, s. 1-4.

${ }^{26}$ Erim, a.g.m., s.18.

${ }^{27}$ Emir-i Kebir lakaplı MirzaTaki Han, sınır komisyonu üyeliği sonrasında görevli olarak gönderildiği Osmanlı Devleti'nde Tanzimat sonrası 1slahatları yerinde görmüştür. İran'a dönüşünde Nasreddin Şah'ın tahta geçmesinde önemli rol oynamış ve 1848'de sadrazamlığa getirilmiştir. 1851 yılında Nasreddin Şah tarafından sürgüne gönderilişine kadar kaldığı bu görev sırasında, Osmanlı Devleti'nde görmüş olduğu islahatların benzerlerini İran'da gerçekleştirmiştir.

28 İbrahim Aykun, Erzurum Konferansı (1843-1847) ve Osmanlı-İran Hudut Anlaşması, Atatürk Üniversitesi, Sosyal Bilimler Enstitüsü (Yayımlanmamış doktora tezi), Erzurum, 1995, s. 76-77. Eserde, konferans öncesi, konferans süreci ve yapılan sınır anlaşmasıyla ilgili ayrıntılı bilgi vardır.

${ }^{29}$ Aykun, a.g.e., ss. 228-238 Taslakta Osmanlı Devleti'nin kabullenmediği en önemli madde, 6. maddedir. Bu maddeye göre Osmanlı Devleti, Muhammere kasabasının tamamını ve Zohab sancağının da bir kısmını İranlılar'a bırakacaktı.

${ }^{30}$ Muahedat Mecmuası, C. III, s. 5-7. Anlaşmanın 2. maddesinde, "Zohab Sancağının cemi arazii basite yani canibi garbisi arazisinin Devleti Osmaniye'ye terkolunmasını Iran Devleti taahhüt eyler ve Devleti Osmaniye dahi Zohab Sancağının canibi Şarkî cemi arazii 
temsilcilerinden oluşan bir sınır belirleme komisyonu (Tahdid-i Hudud Komisyonu) oluşturulmuştur.

Başkanlığını Kimyager Derviş Paşa'nın yaptığı Osmanlı heyeti, 18481852 yılları arasında Basra Körfezi, Basra, Bağdat, Şehrizor, Musul, Van ve Bayezid çevrelerinde çalışmalarda bulunmuştur.

Derviş Paşa, daha komisyon toplanmadan Kotur bölgesinde yapmış olduğu faaliyetlerle Kotur'u Osmanlı yönetimine almıștır. 1850 yılı Ocak ayında toplanabilen komisyon, çalışmalarına aralıklarla devam etmiş, 29 Mart 1852'de Derviş Paşa'ya İstanbul'dan gelen talimatın ardından Osmanlı heyetinin çekilmesiyle komisyonun faaliyetleri son bulmuştur. ${ }^{32}$ İngiltere ve Rusya'nın komisyon çalışmalarını tekrar başlatma çabaları, bir süre sonra Kırım Savaşı'nın başlaması nedeniyle sonuçsuz kalacaktır.

1869'a gelindiğinde, Hariciye Nazırı Mehmed Emin Âli Paşa ile İran'ın Babıâli nezdindeki elçisi Hüseyin Mehmed Han arasında 3 Ağustos'ta bir

cibaliyesinin Gerend deresiyle beraber Iran Devletine terkini taahhüt eder ve Süleymaniye şehir ve sancă̆ hakkında İran Devleti her bir gûna iddiadan sarfinazar edip sancağl mezkûrda olan Devleti Osmaniye'nin hakk temellüküne vakten minelevkat bir gûna dahl ve taarruz etmiyeceğini kaviyyen taahhüt eyler ve Muhammere şehir ve benderi ve Ceziretülhazer ve Lengergâh ve hem dahi sahili şarkî yani canibi yesar Şattülarab'ın Iran'a taallûkları maruf olan aşairin tasarrufunda bulunan arazisi mülkiyet üzere Iran devletinin tasarrufunda olmasını Devleti Osmaniye kaviyyen taahhüt eder ve bundan başka Şattülarab'ın denize münsebb olduğu mahalden tarafeyn hududunun iltihakı mevziine kadar nehr-i mezkurda Iran sefinelerinin serbest-i tamam üzere amedü reft etmeğe haklart olacaktır." ve 3.maddesinde de "İ̧̧bu muahede-i hâzır ile tarafeyni müteahideyn arazi hakkında sair iddiaların terketmiş olup madde-i sabıkaya tatbikan devleteyn beyninde kat'i hudut etmek için iki canipten derakap memurlar ve mühendisler tâyinini taahhüt ederler." denilerek sınırlar belirlenirken; anlaşmanın 8. maddesinde de "Devleteyn-i aliyeteyn-i Íslam serhadde olan aşair ve kabailin garet ve sirkatlerini ref'ü def ve men etmek üzere tedabiri lâzimenin ittihaz ve icrasını taahhüt ederler ve bu husus için münasip mahallerde asker ikame edeceklerdir(...)" denilerek iki ülke arasındaki işbrliğinin kapıları açılıyordu.

${ }^{31}$ Mehmed Hurşid Paşa, Seyâhatnâme-i Hudûd, Simurg Yay., İstanbul, 1997, s. 3. Mektûb-i Hariciyye Kalemi'nde görevli olan Mehmed Hurşid Paşa, Derviş Paşa başkanlığındaki söz konusu komisyonda bulunmuş, dört yıllık görev sırasında gezmiş olduğu şehir ve kasabaların tarihi, coğrafyası ve etnografyası ile ilgili bilgileri içeren Seyahâtnâme-i Hudûd adlı eseri yazmıştır. Eserin önemli özelliklerinden birisi de eserde, bölgede bulunan 1100'e yakın aşiretin isminin geçmiş olmasıdır. Eserin orijinali 1860 yılında ve sadece 150 adet basılmıştır. (Bu konuda bkz. Alâattin Eser, "Bir Hudûdun Anatomisi: Seyahatname-i Hudûd”, Tarih ve Toplum, (Mart 1988), C:9, S:51, s.57-61). İran heyetinin başkanı Mirza Cafer Han, İngiliz temsilcisi Williams ve Rus temsilcisi de Çirikov'dur.

\footnotetext{
${ }^{32}$ Aykun,a.g.e., ss. 246-264.
} 
anlaşma yapıldığı görülmektedir. ${ }^{33}$ Söz konusu anlaşmanın ilk maddesinde, iki tarafça sınırın emniyet ve asayişine dikkat ve itina olunacağ kaydedilmiştir.

İkinci maddede, iki ülke arasındaki sorunlu bölgelerin, dört devlet komiserinin (1847'deki anlaşmadan bahsediliyor), o bölgede incelemelerde bulundukları sıradaki hâliyle kalması kararlaştırılmıştır.

Üçüncü maddede, sorunlu bölgelerin, sorun halledilinceye kadar, hangi ülkenin elindeyse yine o ülkede kalacağ 1 ; dördüncü maddede de kesin bir anlaşmaya varılıncaya kadar bu gibi yerlerde yapı yapılmayacağı, yapılsa bile sahiplenmeye bir delil oluşturmayacağ 1 belirtilmiş, beşinci madde ile de Kazlıgöl'deki harap yapıların onarımına -önceki maddeye bir istisna oluşturmak üzere- izin verilmiştir.

Sınırda çıkabilecek anlaşmazlıkların öncelikle dostça halledilmeye çalış1lacağ1, bunun gerçekleşmemesi durumunda durumun hükûmet merkezlerine bildirileceği ve mahalli makamların, merkezlerden alacakları talimatları bekleyecekleri hükmü, altıncı maddede yer almıştır.

Sözleşmenin yedinci maddesinde, alınan kararların sınırlar kesinleşinceye kadar geçerli olduğu; anlaşmazlıkların, arazi hakkında iki tarafça öne sürülmüş iddia, delil ve protestoların gücünü azaltmayacağı beyan edilmiştir. ${ }^{34}$ Ayrıca anlaşmaya göre iki ülke arasında, Azerbaycan eyaletinde, sinırları tam olarak belli olmayan bir "ara bölge" (Zone Mixte) birakılmıştır. $^{35}$

1874 ve 1875 yıllarında iki ülke, sınır sorunlarını gidermek için yeniden komisyonlar oluşturmuşlarsa da her iki komisyon da sonuç alınamadan dağılmıştır. ${ }^{36}$

İran, gerek Osmanlı Devleti'nin, bat1 sinırlarındaki sorunlarla uğraşmasından, gerekse 1877-1878 Osmanlı-Rus Savaşı'ndan yararlanıp,

${ }^{33}$ Muahedat Mecmuasi, C. III, s. 14.

${ }^{34}$ A.g.e., s. 14.

35 Ragıp İlseven, Türk-İran Hudut İhtilafının Tarihçesi, Dışişleri Bakanlığı Basımevi, Ankara, 1935, s.4-5 (İlseven, sonraları Derviş Paşa tarafından yapılan haritanın, sözkonusu sözleşme üzerinden çizilmiş olduğunu belirtmektedir. İlseven, haritanın bir suretinin, İran sınırındaki konsoloslarımıza gönderildiğini yazmakta ve eklemektedir: " $B u$ haritaya göre, Kürdistan sıradağlarının şark sathı mâilesinden Rumiye gölüne kadar uzanan ve Ardelan vilâyetinde Avraman Dağları'ndan çıkarak Savuç Bulak'ın şarkından Mükri ve Şehrivan arazisinden geçen ve mezkûr göle dökülen Gagatu Nehri ă̆zına kadar giden arazi, iki hükûmet arasında ihtilaflı olan mıntıka gibi görünmektedir. ”)

${ }^{36}$ Aykun, a.g.e., s. 268 
sorunlu bölgenin bir kısmını ele geçirerek sınırı Anadolu tarafina doğru ilerletmiştir. ${ }^{3}$

Savaş sonunda imzalanan Berlin Antlaşması gereğince, İran sınırını belirlemekle görevli Rus ve İngiliz görevlilerden oluşan "muhtelit komisyon"un almış olduğu karar doğrultusunda Kotur şehri ve arazisi İran'a bırakılmıştır.

Berlin Antlaşması'nın imzalanmış olduğu 1878'den 1907'ye kadar geçen süreçte, sınırda küçük çaplı çarpışmalar dışında önemli bir olay meydana gelmemiştir. 1907'de İran'da meşrutiyetin ilanı ve sonrasında çıan karışıklıklar, bölgede yine bir hareketlenmenin yaşanmasına neden olmuş, özellikle Kürt aşiretlerinin Türk köylerine yönelik saldırılarını önlemek üzere Mehmet Fazıl Paşa ve İzzet Paşa komutasındaki birlikler bu bölgeye gönderilmiştir. Bu birlikler, İran'ın önceden ele geçirmiş olduğu yerleri geri almışlardır. ${ }^{38}$ Rusya'da 1908 'de sınır tespiti için oluşturulan karma komisyonun çalışmaları sonucunda, Türk orduları tarafından ele geçirilmiş olan Savuç Bulak, Bana, Serdeşt, Sülduz, Uşna ve Lâheycan, Sine, Rumiye ve çevresi ile Dol, Deşt, Branduz, Terguvar, Merguvar, Somay, Bradoşt ve Selmas'a bağlı yerler Osmanlı Devleti'ne bırakılmıştır. ${ }^{39}$

1911'e gelindiğinde İngiltere ile Rusya, Osmanlı Devleti'ne birer nota vermişler ve 1908 'de Osmanlı'ya bırakılmış olan yerlerin bir ay zarfında tamamen tahliyesini ve daha sonra da Basra körfezinden Ağrı Dağı'na kadar Türk - İran sınırının Rusya, İngiltere, Türkiye ve İran Hükümetleri temsilcilerinden oluşan bir sinır komisyonunca kesin olarak tesbitini istemişlerdir. $\mathrm{Bu}$ isteği karşılamak amacıyla Osmanlı Devleti ve İran arasında yapılan görüşmeler sonucunda 1912'de Tahran'da bir protokol imzalanmıştır. ${ }^{40}$ Protokole göre, aralarında İngiliz ve Rus temsilcilerin de bulunduğu bir "Muhtelit Hudut Komisyonu" kurulması kararlaştırılmıștır. Aynı yıl içerisinde 18 toplantı yapan komisyon, sınır sorunları konusunda herhangi bir çözüme ulaşamamıştır. ${ }^{41}$

Bu arada, Ağustos 1913’te Osmanlı Devleti istenilen bölgeyi boşaltmış; 17 Kasım 1913'te de ikinci isteği yerine getirerek İstanbul'da ilgili devletlerin katılımıyla bir komisyon toplamıştır. Komisyonun çalıșmaları

${ }^{37}$ Erim, a.g.m., s.20-21

${ }^{38}$ A.g.m., s. 21

${ }^{39}$ İlseven, a.g.e., s. 8 (Osmanlı Devleti, Van valisi Tahir Paşa başkanlığında bir heyetle komisyon çalışmalarına katılırken; İran Rumiye hakimi Muhteşemüssaltana ile temsil edilmiştir.)

${ }^{40}$ Barış Metin, Birinci Dünya Savaşı’nda İran Coğrafyasında Etnik, Dini ve Siyasi

Nüfuz Mücadeleleri, (yayımlanmamış doktora tezi), Ankara, 2007, s. 14

${ }^{41}$ A.g.e., s. 14 
sonucunda, Sadrazam Sait Halim Paşa, Britanya büyükelçisi Mallet, İran büyükelçisi Mirza Mahmut Han-1 Kaçar ve Rusya büyükelçisi Giers arasında Türk-İran sınırının tahdidine dair bir protokol imzalanmıştır. Bu protokole göre 1848 statükosu üzerinden tesbiti kararlaştırılan sınırın, dört devletin komiserlerinden oluşan "Tahdid-i Hudud Komisyonu" tarafindan mahallerinde tayin ve işaretlenmesi kabul edilmiştir. ${ }^{42}$

Ayrıca protokolde, komisyonun görevini yerine getirirken protokol hükümlerine ve protokole ekli olan "Tahdid-i Hudut Komisyonu Dahili Nizamnamesi" ne uygun hareket etmesi karara bağlanmıştır. ${ }^{43}$

Osmanlı Devleti komisyon komiserliğine Bnb. Aziz Bey, yardımcılığına da Yzb. Abdülmecid Efendi atanmış, Harita Şubesi tarafından Türk-İran sınırını belirleyen noktalar işaretlenip Matbaa-yı Âmire'de çoğaltıldıktan sonra ilgili vilayetlere, kolordu kumandanlıklarına ve hudut yakınlarındaki şehbenderliklere ${ }^{44}$ gönderilmişlerdir. ${ }^{45}$

Protokolün önemli kararlarından birisi de komisyon çalışmaları sırasında güzergâh belirlenmesine dair olası Türk-İran anlaşmazlıklarında, Rus ve İngiliz komiserlerinin hakemliğine başvurulacak olmasıdır. Böyle bir durumda, Rus ve İngiliz hakemlerinin kararlarının Osmanlı ve İran komiserlerince kabulünün zorunlu olacağı hükme bağlanmıştır. ${ }^{46}$

Protokolün uygulanması için karma komisyonun çalışmalarını Urmiye bölgesinde sürdürdüğü sırada 1. Dünya Savaşı'nın başlaması, Osmanlı Devleti'nin de savaşta Rusya'nın karşısında yer alması, Ruslar'ın komisyonun Türk üyelerini esir almalarına ve komisyonun dağılmasına neden olmuştur. ${ }^{47}$

Savaş sonunda imzalanan Mondros Ateşkes Antlaşması'nın 11. maddesi ile Osmanlı Devleti, savaş sırasında ilerleme gerçekleștirdiği İran'ın kuzeybatısından çekilmek durumunda kalmıştır. ${ }^{48}$ Boşluktan yararlanan

${ }^{42}$ Cevdet Küçük, “İran-Irak Hududunu Belirleyen 1913 Tarihli İstanbul Protokolü”, İstanbul Üniversitesi Edebiyat Fakültesi Dergisi, (Doğumunun 100. Yılında Atatürk'e Armağan), İstanbul, 1981, s. 249.

${ }^{43}$ Küçük, a.g.m., s. 249-250

${ }^{44}$ Konsolosluk.

${ }^{45}$ Metin, a.g.e., s. 15

${ }^{46}$ Bu konudaki en önemli anlaşmazlık, Sumar Ovası ve çevre suları nedeniyle çıkmıştır. Gerek Osmanlı yöneticileri ve gerekse bölge sakinlerinin, İngiliz ve Rus komiserlerin İran yanlısı olduklarına dair suçlamaları vardır. Sumar Ovası'na yönelik anlaşmazlığın ve diğer anlaşmazlıkların ayrıntıları için bkz. Metin, a.g.e., 16-20

${ }^{47}$ Erim, a.g.m., s. 21

${ }^{48}$ İlgili maddede, “Kuzeybatı Iran'daki Türk birliklerinin gecikmeden savaş öncesi sınırların arkasına çekilmesi için daha evvel verilen talimatın yerine getirilmesi” ifadesi 
Şekak Aşireti reisi Simko'nun ${ }^{49}$, bölgedeki hakimiyeti, 25 Haziran 1922'de daha sonra Şah olacak- Riza Han kuvvetleri tarafindan yenilgiye uğratılıncaya kadar devam etmiştir.

\section{Millî Mücadele Dönemi}

1. Dünya Savaşı sonrasında başlayan işgallere karşı Anadolu'da Mustafa Kemal Paşa önderliğinde bir ulusal kurtuluş hareketi başladığ 1 dönemde, komşu İran'da da önemli siyasal gelişmeler meydana gelmiştir.

Savaş sonunda, yabancı orduların çekilmesiyle oluşan iktidar boşluğunu doldurmak isteyen çeşitli grupların mücadelesinin yanı sıra; Ekim Devrimi'ni ülkenin tamamında olgunlaştırmak için Rusya'nın kısa bir süre de olsa kendi kabuğuna çekilmesini firsat bilen İngiltere, zayıf Tahran yönetimine 9 Ağustos 1919 'da bir anlaşma imzalatmıştır. İngilizler'in İran'1 himaye altına almasını sağlayacak olan bu anlaşmanın tıpkı Sevr Antlaşması gibi meclisten geçememiş olması, İngiltere'nin Ortadoğu'da diğer büyük rakiplerine, özellikle de Rusya'ya karşı üstünlük kurmasını engellemiştir.

Diğer taraftan İngilizler'in; gerek Türkler gerekse İranlılar üzerinde uygulamış olduğu baskılar, Tahran'daki milliyetçi hükûmetlerle Ankara hükûmetini, İngilizler'e karşı anti-emperyalist ve tam-bağımsızlıkçı söylemde birleştirmiştir. ${ }^{50}$ Fakat buna rağmen Millî Mücadele Dönemi'nde

vardır. Burada belirtilen talimat, 1911'de verilen ve 1913'te uygulamaya konulacakken savaş nedeniyle gerçekleştirilemeyen talimattır. İran sınırıyla ilgili olarak, hukuken geçersiz olan Sevr Antlaşması'nın 27. maddesinin 4. bendinde, Türk-İ́ran sınırı "89. madde hükümleri saklı kalmak koşuluyla halihazırda mevcut hudut” şeklinde belirtilmiştir ki sözkonusu 89. madde, Türkiye ile Ermenistan arasındaki sınırı ABD Başkanı'nın hakemliğine sunan maddedir.

${ }^{49}$ Simko Ağa, Türk-İran sınır bölgesinde bulunan Şekak Aşireti'nin lideridir. 1. Dünya Savaşı'nın sonlarına doğru Nasturiler'e karşı Osmanlı ordusu ile işbirliğine girmiş, özellikle Mondros Mütarekesi’nden sonra bölgedeki asayişsizliği iyi değerlendirmiş, Türk topraklarında bulunan Şemdinan bölgesinde yaşayan Şeyh Taha adlı bir Kürt aşiret reisiyle ittifak yaparak kısa sürede önemli bir güç oluşturmuştur. 1919 başlarında başlatmış olduğu isyan hareketi ile İran'1 uzun süre uğraştırmıştır. Bölgedeki İngiliz tehlikesine ve Ermeni/Nasturi saldırılarına karşı Ankara ile işbirliği yapıp, bu sayede Türkiye tarafından silah ve mühimmat yardımı almıș olması, alınan bu yardımları Ankara'nın amaçları dışında kullanarak İran'a karşı Şubat 1920'den itibaren bir dizi isyan hareketine girişmesi, üstelik İngilizler'e dayanarak zaman zaman ikili oynaması; hem Ankara-Tahran ilişkilerini olumsuz yönde etkilemiş hem de Ankara'nın Haziran 1922'den itibaren kendisinden desteğini çekmesine neden olmuştur. Bu olumsuz hava, Ekim 1922'de Türk kuvvetlerinin Simko ile çatışmaya girmesi ve Simko'nun Süleymaniye'ye çekilmesi ile sonuçlanmıştır.

${ }^{50}$ Gökhan Çetinsaya, "Milli Mücadele'den Cumhuriyet'e Türk-İran İlişkileri 19191925”, Atatürk Araştırma Merkezi Dergisi, Sayı 48, Cilt: XVI, (Kasım 2000), s.1. 
Ankara ve Tahran arasındaki ilişkiler, başta aşiret reisi Simko olmak üzere, çeşitli nedenlerden dolayı çok dosça bir gelişme göstermemiş̧tir.

İki ülke arasındaki ilişkilerin normal bir seyir izlememesinin bir başka nedeni, Paris Barış Konferansı devam ederken İran hükümetinin Osmanlı Devleti'nden toprak talep etmesidir. İran Dışişleri Bakanı, 26 Mart 1919'da İngiliz Dışişleri Bakanına göndermiş olduğu yazıda, "İran sınırının kuzeyinde, Aras ırmağından başlayarak, kuzeydoğuda Derbend'e kadar uzanan ve sinırı Tiflis, Kars ve Erzurum'un yakınından geçerek Erivan ve Elizabetpol'u da kapsayan bölge"yi İran'1n talep ettiğini belirtmiş ve bu talebi iletmek üzere, Paris Barış Konferansı'na ülkesinin temsilci göndermesini istemiştir. ${ }^{51} \mathrm{Bu}$ başvuru, İngilizler tarafından ciddiye alınmamıştır. İlişkilerdeki bir başka pürüz, İran'ın bu dönemde sürekli olarak Türkler'in İran Azerbaycanı'na yönelik faaliyetlerde bulunduğuna dair şüpheleridir.

Millî Mücadele'nin Yunanlılarla silahlı mücadele safhasının başladığı 1921 başlarında, Şubat 1921'de milliyetçi ve anti emperyalist bir subay olan Rıza Han, bir hükûmet darbesi gerçekleştirmiş, önce ordu komutanlığına, ardından Millî Savunma Bakanlığı'na ve son olarak da Başbakanlığa getirilmiştir. Riza Han, güçlü bir ordu oluşturarak, bir yandan İran içerisindeki ayaklanmaları birer birer bastırıp merkezî devleti güçlendirirken, diğer yandan da ülkenin İngiltere ya da Bolşevik Rusya'nın kontrolüne girmemesi için mücadele etmiştir. ${ }^{52}$

Bu dönemde İran, mevcut sorunların çözümünü görüşmek üzere, 1922 Haziranı'nda Ankara hükûmeti nezdinde Mümtazüddevle adında bir elçi göndermiştir. Bu elçi Ankara tarafından gayet olumlu karşılanmıştır.

Mustafa Kemal Paşa, elçinin gelişiyle ilgili olarak yapmış olduğu açıklamada, “(...) Efendiler, Iran Devleti Aliyesi, Iran milleti muhteremesi hakikaten şark muvazenei umumiyesinde fevkalade haizi ehemmiyet bir kitledir. Şimdiye kadar Türkiye halkı ile Iran halkı hakiki ve candan temasa mazhar olamamıştı. Çünkü başlarında öyle adamlar bulunmuştur ki, onlar buna mani idi. Fakat ben yakinen bilirim ki, Iran milliyetpervaranı pek mukaddes bir arzu için asırlarca uğraşmış, fevkalade kahraman bir millettir. Ĕ̆er Iraniler buna bütün mana ve şümulü ile muvaffak olamamışlarsa bittabi kabahat kendilerinde, mesailerinde değildir. Bu arz ettiğim nokta pek mühimdir. Şimdiye kadar Devleti Aliyei Osmaniye unvanı altındaki imparatorluk ile Devleti Aliyei Iran arasındaki münasebatın Iranlıların ve

\footnotetext{
${ }^{51}$ Salahi Sonyel, Türk Kurtuluş Savaşı ve Dış Politika I, TTK yay., Ankara, 1995, s.42.

${ }^{52}$ Gökhan Çetinsaya, “Atatürk Dönemi Türkiye-İran İlişkileri 1926-1938”, Avrasya Dosyası, 5/3, (Sonbahar 1999), s.148.
} 
Türkiye halkının ciddi temayüllerine mutabık tecelli edememiş olduğunu itiraf etmek lazımdır. Fakat bugün İanlı kardeşlerimiz emin olabilirler ki Türkiye'nin başında bulunanlar aynı adamlar değildir. Mümtazüddevle Hazretlerinin temsil ettiği Iran millet ve devleti, hakiki temas noktasinı bulmuştur. Bunun tecellisi pek feyizli olacaktır. Bu feyizden yalnız Türkiye ve Iran değil, bütün şark milletleri müstefiz olacakttr." diyerek, bu ziyarete vermiş olduğu önemi belirtmiştir. ${ }^{53}$

Oluşan bu olumlu ortam, 7 Ekim 1922'de, Muhittin Paşa (AKYÜZ)'nın Ankara Hükümeti'nin Tahran büyükelçisi olarak atanması ve 30 Ağustos zaferinin kazanılmasından sonra İran'ın zaferi tebrik etmek için bir heyet göndermesi ile daha da pekişmiştir. ${ }^{54}$

\section{Cumhuriyet Dönemi}

Lozan Barış Antlaşması'nın kendisine yaratmış olduğu hukuki zemini değerlendiren ve 29 Ekim 1923'te cumhuriyeti ilan ederek yeni devletin, rejimin ve devlet başkanını adını koyan Türkiye, yeni rejimin İran'da da benimsenmesi için büyük çaba harcamıştır. İran'da mevcut Türk kökenli Kaçar Hanedanı'nın son üyesi Şah Ahmed'in Avrupa'da yaşamakta olması ve Türkiye'de cumhuriyetin ilanından bir gün önce, 28 Ekim'de başbakanlığa getirilen Rıza Han'ın cumhuriyet rejimine taraftar tutumu,

${ }^{53}$ İran, İstanbul hükûmeti nezdindeki elçisini de bulundurmaya devam etmişse de bu durumun Ankara Hükûmeti için bir sorun olarak görülmediği ve İstanbul'daki elçinin muhatap alınmadığı, 14 Temmuz 1922'de, Azerbaycan büyükelçisi İbrahim Abilev tarafından, İran elçisi Mümtazüddevle’ye verilen yemekte Mustafa Kemal Paşa'nın yapmış olduğu konuşmadan anlaşılmaktadır. Bu konuşmasında Mustafa Kemal Paşa, "Iran devlet-i aliyesi Ístanbul'da bir sefir bulundururken Ankara'ya da Mümtazüddevle hazretlerini memur etmekle cihanda hasıl olan intibaha iştirakini göstermiş olmaktadır. Bizim için İan hükümetinin sefir-i hakikisi Mümtazüddevle hazretleridir. Bu itibarla artık İstanbul'da bulunan sefirin slfat ve selahiyetinin keenlemyekun olduğuna şüphe etmemek lazımdır. (...) Iran'a gerek şimalden, gerek cenubdan artık ecnebi tesir ve nüfuzunun gelmemekte olduğunu İan'ın muhterem mümessilinin ă̆zından işitmiş olmakla fevkalade bahtiyarım.." demiştir. Hakimiyet-i Milliye, (9 Temmuz 1922).

${ }^{54}$ Salar Nizam adlı bir İranlı subayın başkanlığını yaptığı heyet, 22 Ekim 1922'de Ankara'ya gelip 2 Kasım'da Mustafa Kemal Paşa ile görüşmüş ve beraberlerinde getirmiş olduğu hediyeleri sunmuştur. Bkz. Zeki Saruhan, Kurtuluş Savaşı Günlüğü IV: Sakarya Savaşı'ndan Lozan'ın Açılışına, TTK yay., Ankara, 1996, s.770 ve 821 (Saray, Muhittin Paşa'nın atandığı tarih olarak 23 Şubat 1923'ü göstermiştir ki bu tarih, Muhittin Paşa'nın göreve başladığı tarihtir. Bkz. Mehmet Saray, Türk - İran İlişkileri, AAM yayınları, Ankara, 1999, s. 113). 
Türkiye'nin bu çabalarını kolaylaştırıcı bir etken olarak görülmüştür. ${ }^{55}$ Türkiye'nin bu desteğinde iki temel sebep vardı. Birincisi, Türk devriminin diğer İslam ülkelerine de model olabilmesi, diğeri ise Türkiye'nin İran'1 yabancı devletlerin boyunduruğundan çıkmış, bağımsız bir ülke olarak görme arzusuydu. ${ }^{56}$

Başlangıçta Rıza Han, cumhuriyetin ilanı konusunda gerek halkın, gerek basının ve gerekse İran ulemasının desteğini almış görünüyordu. $\mathrm{Bu}$ nedenle Şubat 1924'ten itibaren bu konuya yönelik girişimlerini hızlandırmıştır. Fakat daha sonra ulemanın cumhuriyet karşıtı bir tavır içerisine girmesi, hem halkı hem de İran meclisindeki milletvekillerini etkilemiştir. Sonuçta Rıza Han, 1 Nisan 1924'te bir bildiri yayınlamış ve cumhuriyetin ilanı fikrinden vazgeçtiğini açıklamıştır. ${ }^{57} \mathrm{Bu}$ gelişmeden kısa bir süre sonra, İran'ın Türkiye'deki büyükelçisini değiştirmesi, üstelik Eylül 1924'te Türkiye'ye varan yeni büyükelçi Tabatabai'nin bir din adamı oluşu, halifelik kurumunu henüz kaldırmış olan Türkiye tarafindan anlamlı bulunmuş ve bu durum, Türkiye'nin İran ile daha yakın ilişkilere girmesinin bir süre daha ertelenmesine neden olmuştur.

Ağustos 1925'te Memduh Şevket (ESENDAL) Bey, Tahran büyükelçisi olarak atanmıştır. 7 Kasım 'da göreve başlayacak olan yeni büyükelçi göreve başlamadan kısa bir süre önce, 31 Ekim 1925'te İran Meclisi, Kaçar hanedanlığını sonlandırmıştır. 12 Aralık'ta Rıza Han, "şah" ilan edilmiş ve Türkiye, bir süre İran'daki siyasal gelişmeleri gözden geçirdikten sonra Memduh Şevket Bey'in de tavsiyesiyle- M.Kemal Paşa'nın 5 Ocak 1926 tarihindeki tebrik mektubu ile yeni rejimle ilişkileri başlatmıştır. ${ }^{58}$ Atılan bu önemli adım, kısa sürede meyvelerini vermiş ve 22 Nisan 1926' da iki ülke arasında bir dostluk ve güvenlik anlaşması imzalanmıştır.

\section{Anlașması ve Sonrasındaki Gelişmeler}

Osmanlı Devleti'nin sona ermesiyle birlikte mevcut tüm anlaşmaların ortadan kalkmış olması, iki ülke arasındaki ilişkilerin yasal bir zemin üzerine oturtulmasını gerekli kılmıştır. 1926'nın ilk günlerinde, yukarıda belirtilen temaslarla başlayan sıcak ilişkiler, resmi bir anlaşma çabalarını beraberinde getirmiştir. Tahran büyükelçisi Memduh Şevket Bey, Rıza Şah'ın güvendiği

55 Şimşir, Rıza Han'ın cumhuriyetin ilanına yönelik bu olumlu tutumunda, Mustafa Kemal Paşa'nın Tahran büyükelçisi Muhittin Paşa kanalıyla yapmış olduğu tavsiyelerin etkili olduğunu belirtmektedir. Bkz. Şimşir, Bizim Diplomatlar, Bilgi Yayınevi, İstanbul, 1996, s.86-87.

${ }^{56}$ Çetinsaya, "Millî Mücadele'den....”, s. 10.

${ }^{57} \mathrm{Bu}$ konuyla ilgili geniş bilgi için bkz. Çetinsaya, a.g.m., s. 9-11

${ }^{58}$ Şimşir, a.g.e., s. 89 
bir isim olan ve aynı zamanda Saray Nazırlığı'nı da yürüten Timurtaş ile birlikte, anlaşmaya giden yolda bir dizi gizli görüşmede bulunmuşlardır. Görüşmenin gizli yürütülmesinin nedeni, Moskova ve Londra'ya sızabileceği endişesidir. ${ }^{59}$

Zaman zaman kesilme tehlikesi yaşanan görüşmeler sonunda 22 Nisan'da Tahran'da “Türkiye Cumhuriyeti ve Iran Devleti arasinda Emniyet ve Muhadenat Muahedenamesi" imzalanmıștır. Anlaşmanın ikinci maddesi, tarafların herhangi birine bir askerî hareket meydana geldiğinde, diğerinin tarafsız kalmasını öngörmüştür. Üçüncü madde taraflara birbirlerine karşı herhangi bir siyasi ve mali ittifaka girmeme yükümlülüğü getirmiş, dördüncü madde ise tafasızlık kavramını daha ayrıntılı hâle getirmiştir. Beşinci madde, birbirlerine karşı düşmanca eyleme girişebilecek şahıs ya da grupların ikametini iki ülkeye de men etmiştir.

Doğrudan sınır bölgesiyle ilgili olan altıncı madde, "Tarafeyni akideyn hudut mintzkalarl ahalisinin huzur ve emniyetlerini temin edebilmek maksadiyle hudut civar arazide bulunan aşiretlerin ihdas edegelmekte oldukları iki memleketin asayişini muhilli efaü mücrimaneye ve tertibata nihayet vermek için bilcümle tedabiri lâzimeyi ittihaz edeceklerdir. Bu tedabir tarafeyn hükümetlerince ayrı ayr veya lüzumuna kail olduktan takdirde müştereken ittihaz olunacaktır." Böylelikle, yıllardır süren sınır asayişsizliklerinin önleme konusunda ciddi bir adım atılmıştır.

Anlaşma ile İran, Türkiye'nin İran Azerileri’ne yönelik sürdürdüğünü düşündügüu propaganda faaliyetleri konusunda rahatlayabilecek; Türkiye de sınırdaki aşiretlerin kendisine karşı gerçekleştirdiği ayaklanmaların arkasında İran'ın olmadı̆̆ından emin olabilecekti.

Fakat bu iyimser ortam fazla uzun sürmeyecek ve anlaşmanın imzalanmasında kısa bir süre sonra başlayacak olan I. Ağrı Ayaklanması (16 Mayıs - 17 Haziran 1926) ${ }^{61}$ sonrası sınır bölgesinde Türkiye'nin başlatmış

${ }^{59}$ Çetinsaya, “Atatürk Dönemi....", s. 152

${ }^{60}$ TBMMZC, Devre: 2, Cilt: 25, İctima: 3, 105. İnikat, (22.05.1926), S.say1s1: 198, s. 417.

${ }^{61} 1926$ yılı Mayıs ayının ilk günlerinde Yusuf Taşo adlı çete reisinin İran sınırını geçip Doğubeyazıt bölgesindeki köylerden hayvan çalarak Ağrı yaylalarına sığınması ve harekete karşı devletin almış olduğu önlemler; Suriye'de faaliyet göstermeye başlayan ve bir KürtErmeni dayanışması denilebilecek "Hoybun" adlı örgütün olayı siyasallaştırıp, genel bir ayaklanma başlatmasına neden olmuştur. Bu konuda bkz. Türkiye Cumhuriyeti’nde Ayaklanmalar, Genelkurmay Harp Tarihi Başkanlığı yay., Ankara, 1972, s.168-173 ; ayrıca bkz. Abdulhaluk Çay, Her Yönüyle Kürt Dosyası, Ankara, 1994, s.405-412 
olduğu uçaklarla destekli kara harekâtı, İran tarafından çok da hoş karşılanmayacaktır.

Sınırın her iki tarafındaki aşiretlerin gerçekleştirdikleri sınır tecavüzleri ve eşkıyalık hareketlerini önlemek için 1927 yılı ortalarında itibaren Türkiye'nin bazı sınır karakollarını ileri taşıması, İran'ın tepkisini çekecek ve resmi olarak olmasa da basın yoluyla İran tarafindan Türkiye'nin suçlanmasına neden olacaktır. Türk tarafındaki silahlı çetelerin İran topraklarına saldırmasına Türkiye'nin seyirci kalmasından başlayıp; Türkiye'nin İran topraklarında emperyalist emelleri olduğu iddialarına kadar uzanan bu suçlamalara yanıt, Türkiye kanadından da basın yoluyla verilecektir. $^{62}$

Tam da bu dönemde sınırdaki bazı aşiretler, 1927 Eylülü'nde tekrar isyan başlatmışlardır. $\mathrm{Bu}$ isyan hareketini bastırmak üzere 13-20 Eylül tarihleri arasında II. Ağrı Harekâtı başlatılmıştır. Harekât sırasında isyancıların bir kısmı sınırı geçerek İran'a sığınmışlardır. Bu durum, İran'ın aşiretler politikasının, önceki olayda olduğu gibi sadece basın tarafindan değil, Türk Hükûmeti tarafından da tasvip edilmemesine neden olmuştur.

İlişkilerin gerilmesi üzerine Memduh Şevket Bey'in Ankara'ya çağırıldığı görülmektedir. Bu çağrılış resmi olarak "nazik ikili ilişkiler hakkında kendisine danışılmak üzere" şeklinde açıklanırken, basında bu çağrının büyükelçi çekme şeklinde gerçekleştiğine dair yorumlar bulunmaktadır. ${ }^{63}$

Memduh Şevket Bey, Ankara'ya gelmeden önce Tahran'ın İngiliz elçisiyle bir görüşme yapmış, bu görüşmede Türk makamlarının aşiretleri silahsızlandırmak için elinden geleni yaptığını, fakat eşkıyanın İran tarafından her zaman silah satın alabildiğini belirterek İranlı yetkilileri bu

${ }^{62}$ Özellikle Cumhuriyet gazetesi başyazarı Yunus Nadi, bu dönemde köşesinde İran'da çıkan yarı resmi İan ile Cent'te yer alan Türkiye aleyhtarı yazılardan alıntılar yaparak bunlara yanıt vermektedir. Nadi özellikle gazetelerdeki suçlamaların o dönemdeki sınır sorunlarını aşıp, yıllar öncesindeki sorunları da içine alacak şekilde genişletilmesini ; diğer taraftan bu gibi gazetelerin Türklerin yaptıkları her yeniliğin (örneğin 1907'de İran'da Meşrutiyet ilanından hemen sonra 1908'de Osmanlı Devleti'nde ilanı gibi) İran'dan kopya çekilmiş gibi gösterilmesini eleştirmektedir. Ona göre bu iki komşu ülkenin dostluğunu bozmak isteyen bir düşman vardır ve bu düşman da İngiltere'dir. Örnek olarak, bkz. Yunus Nadi, “Komşumuz İran”, Cumhuriyet, (10 Ağustos 1927)

${ }^{63}$ Cumhuriyet, 27 Eylül 1927. 
konuda suçlamıştır. ${ }^{64}$ Özetle Ankara, İran'ın 1926 anlaşmasına uygun olarak, sınırda daha aktif bir politika izlemesini istemektedir.

Durumun nezaketini anlayan İran, ilişkilerin düzeltilmesi için Harbiye Nazırı olan ve o sırada İsviçre'de İran'ın Milletler Cemiyeti temsilcisi olarak bulunan Furugi'ye, 1927 Sonbaharı'nda Türkiye'ye gitmesi ve sorunu görüşerek ilişkileri düzeltmesi talimatını vermiştir. ${ }^{6}$

Furugi'nin Türkiye gelişinden önce iki ülke ilişkilerini olumsuz etkileyecek bir olay daha yaşanmıştır. Bayezid Hadisesi olarak adlandırılan bu olayda, İran sınırından gelen silahlı çeteler, Doğubeyazıt yakınlarında Türk birliğini pusuya düşürüp subay ve erlerden bir kısmını esir alıp kaçmışlardır. Türkiye İran'a 10 gün süreli bir nota vermiş ve İran'1, gerekli önlemlerin almaması durumunda ilişkilerin kesilmesiyle tehdit etmiştir. Vermiş olduğu yanıtta söz konusu grupların kendileriyle ilgilerinin bulunmadığını, bu grupların İran Kürtleri'nden dahi olmadıklarını belirten İran, sınırda da önlemler almaya başlamış, esir subay ve askerlerin serbest bırakılması için de çaba harcamıştır. Bu çabalar sonuç verince ilişkiler normalleşmiş ve İran aleyhinde basında çıkan haberler, yerini daha olumlu yaklaşımlara bırakmıştır.

$\mathrm{Bu}$ arada yukarıda belirtilen talimatı aldıktan kısa bir süre sonra Türkiye'ye gelen ve uzun bir süre İstanbul ve Ankara'da temaslarda bulunan Furugi'ye Türk tarafının görüş ve istekleri net olarak iletilmiştir. Buna göre Türkiye, görüşmelerde 1913 protokolünü (Sait Halim Paşa'nın imzalamış olduğu protokol) temel almak istememektedir. Çünkü bu protokol Osmanlı Devleti'nin zayıf olduğu bir dönemde neredeyse Rusya ve İngiltere tarafından dikte ettirilmiş bir protokoldür. Dahası, artık Osmanlı Devleti tarihe karışmıştır.

Türkiye'nin diğer isteği, isyancı grupların İran sınırını kolayca geçip İran içlerine kaçamamaları için İran'ın tedbir almasıdır. Furugi ise Türkiye'nin isyancıları takip nedeniyle İran sınırlarını geçmesinden, hükûmetinin duymuş olduğu rahatsızlığı dile getirmiştir. 1913 Protokolünü kabul etmeyen Türkiye'yi; 1913 sonrasında mevcut sinırları bazı noktalarda ihlal etmekle, hatta I. Dünya Savaşı'nda dile getirdiği Azerbaycan topraklarıyla ilgili isteklerini de belli ölçüde tekrarlayıp irredantizm ${ }^{66}$

${ }^{64}$ Çetinsaya, “Atatürk Dönemi....”, s. 156. Ayrıca Memduh Şevket Bey, 1913 protokolünün Osmanlı Hükûmeti tarafindan hiçbir zaman onaylanmadığını bu yüzden sınır meselesi çözümünün fazla zor olmayacağını belirtmektedir.

${ }^{65}$ A.g.m., s. 156.

${ }^{66}$ Dil, gelenek, görenek ve çeşitli kültür değerleri bakımından bir birlik gösterdiği hâlde ana yurt dışında kalmış halkın yaşadığı toprakları ana yurt sınırları içine almak düşüncesi, kurtarımc1lık. 
yapmakla suçlayan Furugi, görüşmelerde gelinen son noktayı Tahran'a bildirmiş ve 45 günlük Ankara ziyaretini tamamlayıp İstanbul'da hükûmetinin yanıtını beklemeye başlamıştır. ${ }^{67}$ Furugi, Nisan 1928'de tekrar Ankara'ya gelip Haziran sonuna kadar sinırla ilgili olarak görüşmelerde bulunduysa da, özellikle 1913 Protokolü konusu, görüşmelerin tıkanmasına neden olmuştur.

Ankara'daki bu olumsuzluklara karşın, Tahran'da büyükelçi Memduh Şevket Bey'in diğer konularda İranlı yetkililerle yapmış olduğu temaslar olumlu sonuçlanmış ve 15 Haziran 1928'de, 1926'da yapılan anlaşmaya ek bir protokol eklenmiştir.

Tahran büyükelçisi Memduh Şevket Bey, Moskova büyükelçisi Mehmet Tevfik Bey ve İran Dışişleri Bakanı Pakrevan arasında yapılan protokole göre, taraflardan birinin bir ya da birkaç devlet tarafindan saldırıya uğraması durumunda, diğer taraf duruma çare bulmak için gereken çabayı gösterecek; ekonomik alanda sıkı bir işbirliği sağlanacak ve transit geçiş ve ulaşım olanaklarının artırılması konusunda her iki tarafça uzmanlar atanacaktır. ${ }^{68} \mathrm{Bu}$ protokolle Türkiye, İran'1 sınırda daha aktif bir politika izleme konusunda, 1926 anlaşmasına göre daha fazla yükümlülük altına sokabilmiştir.

Sınır konusu ise hâlâ çözümlenmeye muhtaç olarak ortada durmaktadır. Kesilen görüşmelere Furugi'nin Şubat 1929 ortalarında Ankara'ya gelişiyle tekrar başlanmıştır. Türkiye'nin, 1913 Protokolünü kesinlikle kabul etmeyeceğini ve I. Dünya Savaşı sırasında sınırlarına katmış olduğu bölgelerden çekilmeyeceğini bir kez daha kesin bir dille bildirmesi üzerine Furugi, hükûmetine danışmak için İran'a gitmiş, Nisan başlarında dönmüş ve nihayet uzlaşmaya varılabilmiştir. ${ }^{69}$

Sorun, bir an önce çözülmesi için karşıllklı nota verilmesi şekliyle çözümlenmiştir. Sorunun bu şekilde çözümlenmesinde, daha önce iki ülke arasında yapılan anlaşma ve protokollerin uzun süre onay aşamasında beklemesi önemli bir etkendir. Notalarda üç nokta üzerinde özellikle durulmuştur. Bu noktalar, Bulakbaş1, Kotur ve Siro-Sarteks'dir.

Notalara göre, 1929 yaz aylarında kurulacak bir karma komisyon, yukarıda adı geçen bölgelere gidip sınır incelemelerinde bulunacak ve sınırları belirleyip işaretleri yerleştireceklerdir. Komisyon, diğer bölgelerde kaybolmuş işaretler varsa, bu yerlerdeki sınır belirleyici işaretleri yenileyeceklerdir. ${ }^{70}$ Ayrıca yılda en az iki kez toplanacak bir sinır

\footnotetext{
${ }^{67}$ A.g.m., s. 158.

${ }^{68}$ Soysal, a.g.e., s. 279-80.

${ }^{69}$ Çetinsaya, a.g.m., s. 160-161.

${ }^{70}$ A.g.m., s. 162.
} 
komisyonu kurulacak ve bu komisyon iki tarafin sınır otoriteleriyle sürekli ilişki içerisinde olacaktır. ${ }^{71}$

Nisan 1929'daki bu gelişmeyle beraber, sınırda aşiretlerden kaynaklanan hareketlilik devam etmektedir. Bu arada Türkiye, bir yasa çıkararak bölgede toprak reformu yapacağını açıklamış ve bu işi takip için de Umumi Müfettiş olarak İbrahim Tali (ÖNGÖREN) Bey'i görevlendirmiștir. ${ }^{72}$ Fakat bu reform da isyancıların hareketlerinden vazgeçmelerini sağlayamayınca, yeniden askerî önlemler alma yoluna gidilmişsir.

Bakanlar Kurulu, 28 Aralık 1929'da Cumhurbaşkanı Mustafa Kemal Paşa, Genelkurmay Başkanı Fevzi Paşa ve 1'inci Umumi Müfettiş İbrahim Tali Bey'in de hazır bulundukları bir toplantıda, 1930 yılı Haziran ayının son haftasında ve hasat mevsiminden önce, 9'uncu Kolordu Komutanlığ 1 yönetiminde, Ağrı'da bir tenkil harekâtı yapılmasını kararlaştırmış ve kararı ilgili makamlara bildirmiştir. ${ }^{73}$ Fakat daha sonra harekâtı yapmakla görevli 9'uncu Kolordu Komutanlığı' 'nın yapmış olduğu arazi etüdü sonucu, planın Eylül ayına bırakılması teklifi kabul edilmiştir. ${ }^{74} \mathrm{Bu}$ kararda, Genelkurmay'ın da olası bir ayaklanmanın ilkbaharda olamayacağını tahmin etmesi de önemli bir etkendir. ${ }^{75}$

Bölgedeki hareketlilik Haziran ayına gelindiğinde artmaya başlamıştır. Haziran başlarında isyancıların harekete geçmesi üzerine, Mart ayında 9'uncu Kolordu Komutanlığı'na getirilen Salih Paşa (OMURTAK) komutasındaki Türk birlikleri, 9-10 Haziran'da isyancıları çember içerisine

\footnotetext{
${ }^{71}$ Nitekim kurulan sınır komisyonunun, çeşitli aşiret reisleriyle görüşmeler yaptığı, bölgeden Ankara'ya yollanan bilgilerden de anlaşılmaktadır. Bunlardan birinde Halekanlı aşiretinden Halit ve Tozu Ağalar'ın komisyon üyeleriyle beş altı saat görüştükleri rapor edilmektedir. Bkz. BCA, Tarih:03/09/1929, Dosya:9236, Fon Kodu:30..10.0.0, Yer No: 112.753..14. (Ağrı Dağı eşkıyası hakkında Bayezit vilayetinden alınan şifre.)

${ }^{72}$ Uğur Mumcu, Kürt-İslam Ayaklanması (1919-1925), Tekin Yayınları, Ankara, 1995. s.238

${ }^{73}$ Genekurmay Belgelerinde Kürt İsyanları, Kaynak Yayınları, İstanbul, 1992, s. 9293

74 A.g.e., s.112 ( 9'uncu Kolordu Komutanlığının, 3 Mayıs 1930'da yapmış olduğu teklifi uygun bulmuş ve kendi görüşünü de eklemek suretiyle 6 Mayıs'da Başbakanlığa arz etmiştir. Teklif, Bakanlar Kurulunun 8 Mayıs'daki toplantısında kabul edilerek ilgili bakanlıklara ve 9'uncu Kolordu Komutanlığı'na bildirilmiştir.)

${ }^{75}$ Genelkurmay Başkanlığı'nın bu konudaki görüşleri şöyledir: “(...) İlkbahar ekim mevsimi olduğuna ve ayaklanması muhtemel havali halkının idhar edilmiş iaşe maddelerine ihtiyacı olacağına göre, sonbaharda veya bizi daha fazla güçlüğe uğratmak için klşın vukua gelmesi daha çok muhtemeldir ve geçen senelerin tecrübeleri de bu görüşü teyid edecek niteliktedir (...)” A.g.e., s. 109
} 
almışlar ve savaş uçakları da kullanılarak isyancıların sığınaklarını tahrip etmişlerdir. Bu sıkışık durum karşısında isyancılar, önce İran topraklarına kaçmışlar, ardından da İran'da yaşayan Belikanlı ve Halikanlı aşiretlerinin yardımıyla yeniden Türk sınırına doğru saldırıya geçmişlerdir. ${ }^{76}$

Saldırıya İranlı aşiretlerin vermiş olduğu katkı, hem Türk Hükûmeti hem de Türk basını tarafından eleştirilmiş ve İran açıkça suçlanmıştır. Büyükelçi Memduh Şevket Bey aracılığıyla Temmuz başında İran'a verilen notada, bu gibi hareketlerin iki ülke ilişkilerini bozabileceği vurgulanarak, "Iran'in isyancllara müzaheretten vazgeçmesi ve Iran topraklarına iltica eden çeteleri tenkil etmesi" istenmiştir. ${ }^{77}$ İran'ın maslahatgüzarı Mehmet Sait Han, Cumhuriyet Gazetesi'ne bir açıklama yaparak, "Biz Türkiye'nin dahili asayişini ihlal edecek bu kabil hareketleri müdafaa ve teşvik etmeyiz. Bilakis kınarız." ${ }^{78}$ demiştir.

Bir süre sonra yarı resmi yayın organı "İran" aracılığıyla bir açıklama yapan İran Hükûmeti, Türkiye'nin iddia ettiği gibi asilerin İran'da silahlanarak saldırıyı gerçekleştirdikleri tezinin doğru olmadığını, olaylar üzerine sınırı kapattıklarını açıklamış ve güvenliği üst düzeye çıkarmak için sınır memurlarının birlikte çalışmalarını teklif etmiştir. ${ }^{79}$

$\mathrm{Bu}$ açıklamayı çok da tatminkar bulmayan Türkiye, İran'ın notaya yanıtını geciktirmesi ve sınırdaki durumda değişiklik olmaması üzerine aynı ay içerisinde ikinci notayı vermiştir. Daha öncekine göre daha 1lımlı bir üslup içerisinde yazılan notada bu kez İran'a iki seçenek önerilmiştir. Önerilen ilk seçenek, sınır hattının değiştirilerek Ağrı Dağı'nın tamamının Türkiye'ye verilmesi, ikinci seçenek ise Türk birliklerine İran topraklarında sicak takip hakkı tanınmasıdır. ${ }^{80}$

İran, yanıt içeren notasını 9 Ağustos'ta vermiştir. Buna göre İran, Türk birliklerine sıcak takip hakkı vermeyi reddetmiş, her iki ülkenin de sınırda birbirinden bağımsız ama işbirliğine dayanan operasyonlar yapmasını önermiştir. ${ }^{81}$ Türkiye bu yanıta hemen tepki göstermemiş, İran'ın politikasını izlemeye almıştır. İran Şahı'nın emriyle, İran'a sığınmış isyancılar ile onlara yardımcı olanlara karşı operasyonlar başlatılması üzerine, 1lımlı bir politika izlenmeye başlanmıştır.

${ }^{76}$ Saray, a.g.e., s. 115.

${ }^{77}$ Milliyet, 6 Temmuz 1930.

${ }^{78}$ Cumhuriyet, 7 Temmuz 1930.

${ }^{79}$ Vakit, 23 Temmuz 1930.

${ }^{80}$ British Documents on Foreign Affairs : report and papers from the foreign Office Confidental Prints, Part II: Persia, vol. X, doc.13, (06.08.1930)'dan akt; ÇETINSAYA, a.g.m., s. 163

${ }^{81}$ Milliyet, 10 Ağustos 1930. 
$\mathrm{Bu}$ arada büyükelçi konusunda da bir kan değişikliğine gidilmiş, Memduh Șevket Bey merkeze alınırken, o sırada Sofya büyükelçiliği görevini yürüten ve Mustafa Kemal Paşa'nın yakın arkadaşı olan Hüsrev (GEREDE) Bey 16 Temmuz'da Türkiye'ye çağrılmış, devlet erkânı ile yapmış olduğu birebir görüşmelerde almış olduğu talimatlarla 25 Ağustos'ta Türkiye'den ayrılmıştır. ${ }^{82}$

Bu arada 7-14 Eylül tarihleri arasında Türkiye, Ağrı bölgesinde "tenkil harekatı" gerçekleştirerek, III.Ağrı İsyanı'nı kesin olarak bastırmış, ileri harekâtla Aybey bölgesi de dahil olmak üzere bazı arazi parçalarında kontrolü sağlamıştır.

Hüsrev Bey, 15 Eylül'de Şah'a itimatnamesini sunmuş ve Şah ile ilk görüşmesini yapmıştır. $\mathrm{Bu}$ görüşme sırasında Hüsrev Bey, maddi nedenler nedeniyle İran topraklarından isyancilara yardım yapanlara meydan verilmemesi gerektiğini belirterek olaylarda Rusya ve İngiltere'nin de parmağı olabileceğine dikkat çekmiş, olayları ortak bir askerî harekât ile önleme teklifi yapmıştır. ${ }^{83}$ Bu teklife net bir yanıt vermeyen Şah, Türk basınında ülkesi ve şahsına ait yer alan haber ve karikatürlerden yakınmıştır.

Ankara Hükûmeti, 25 Eylül 1930 tarihinde Türk-İran sınırı konusunda Bakanlar Kurulu'nun belirlediği düzenlemeyi, talimat olarak Hüsrev Bey'e bildirmiştir. Hüsrev Bey, talimatı aldıktan sonra Ankara'ya, daha önce Genelkurmay Başkanı Fevzi Paşa ile Ankara'da yapmış olduğu görüşmede, Fevzi Paşa'nın sınırla ilgili olarak bazı hususlara dikkat çektiğini bildirip, bu

${ }^{82}$ Hüsrev Bey, Mustafa Kemal Paşa ile yapmış olduğu görüşmede Gazi'nin kendisine "Hüsrev, pasaportun cebinde... Fakat dönmeni değil, orada kalmanı ve hudut meselesinin halli ile sulh ve dostluk siyasetimizde muvaffak olmanı isterim." dediğini belirtmektedir. İsmet Paşa'nın direktifleri ise daha serttir: "Hüsrev senin durumun tıpkı Osmanlı Imparatorluğu'nun inhitat devirlerinde filolarını Çanakkle Boğazı'na dayayarak sefaret tercümanlarını Babılai'ye gönderip sadrazama arzularını dikte ettiren devletlerin sefirlerine benzemektedir. Bir farkla ki, devletimiz yurt içinde asayişin ihlaline ve hudutlarında bir Makedonya teşekkülüne mani olmak meşru hak ve azmiyle seni göndermektedir. Binaenaleyh sen Iran Hükûmetiyle, seferber olmuş bir ordumuz arkanda, harekete hazır bir halde konuşacaksın. Bu ciddi vaziyetin icabına göre davranmaklı̆̆ın lazımdır." Bkz. Hüsrev GEREDE, Siyasi Hatıralarım I - İran, Vakit Basımevi, İstanbul 1952, s. 17 ve 20. Görüldüğü gibi Cumurbaşkanı İran konusunda 1lımlı bir tutum izlerken, Başbakan sertlik yanlısıdır. Aslında büyükelçi değişikliğinde bu görüş ayrılığının da etkisi vardır. Çetinsaya'ya göre Memduh Şevket Bey, "İran yanlısı" suçlamasıyla merkeze alınmıştır ve bu suçlamada İran politikasında "şahinler" grubunu oluşturan Başbakan ve Dışişleri Bakanı Tevfik Rüştü (ARAS) Bey'in etkisi büyüktür. Diğer taraftan Saray Nazırı Timurtaş da Memduh Şevket Bey'in görevden alınmasına Türk Genelkurmayı'nın neden olduğu düşüncesindedir. (Bkz. Çetinsaya, a.g.m., s.163 ve 165)

${ }^{83}$ Gerede, a.g.e., s. 69 
hususların da bu talimata eklenip eklenmeyeceği konusunu Ankara'ya danışmıştır. Fakat Hüsrev Bey’in deyimiyle “(...) göndermiş oldukları talimatta postalarımızın işgal eyledikleri yerlere mukabil Iranlılar'a verilecek tavizat hakkında birbirini tutmayan, zıt iki karar olduğu için (...) ${ }^{\prime \prime c 64}$ bu konuda acele bir adım atmaktan kaçınmıştır.

Karşılıklı verilen notalarla süreç uzamış, konu bir türlü çözüme kavuşamamıştır. Bunun üzerine, müzakerelerin Ankara-Tahran arasında ve dışişleri düzeyinde değil, bizzat kendisi tarafindan yürütülmesi konusunda Hüsrev Bey'in Ankara'ya iletmiş olduğu teklif, Ankara tarafından kabul edilmiş ve sınır görüşmeleri Mayıs 1931'den itibaren Tahran'dan yürütülmeye başlanmıştır. $\mathrm{Bu}$ durum, çözüm sürecini hızlandırmış, Hüsrev Bey yaz boyunca Askeri Ataşe Kurmay Binbaşı Neşet (KIPER) Bey ile birlikte, Furugi başkanlığındaki İran heyetiyle yapmış olduğu görüşmelerde bir hayli ilerleme katetmiştir. ${ }^{85}$

Ağrı çevresindeki "tenkil harekâtı" sırasında ele geçen Aybey bölgesi de dahil olmak üzere Ağrı Dağı'nın tamamını isteyen Türkiye, karşı1lı̆ında İran'a iki ayrı toprak parçası vermeyi teklif etmiştir. Aybey konusunda Türkiye'nin kararlı olduğunu gören ve bunu kabul etme noktasına gelen İran tarafindaki temel sorun ise Türkiye'nin istediği toprakların stratejik öneme sahip oluşudur. İran gerekirse konunun çözümünde Cemiyet-i Akvam'ın hakemlik yapmasını istemektedir.

Hüsrev Bey, hem görüşmelerde sağlanan gelişmeleri aktarmak hem de son talimatı almak üzere Ekim ayı içerisinde Türkiye'ye gelmiştir. Devlet erkânı ile yapmış olduğu görüşmeler bitmek üzere iken Tahran'daki maslahatgüzar Tahir Numan Bey'den, “İran'1n bir tepe üzerinde 1srar eden bir olumsuz bir nota verdiği ve bu yüzden görüşmelerin tıkanabileceğil"ne dair bir yazı alması üzerine Hüsrev Bey, durumu bildirmek üzere Cumhurbaşkanı Mustafa Kemal Paşa'yı ziyaret etmiştir. Ziyaret sırasında kaydedilen ilerlemeleri ve son tatsız gelişmeyi anlatan Hüsrev Bey, kendisiyle beraber Dışişleri Bakanı Tevfik Rüştü Bey'in de İran'a gelmesinin uygun olacağını söylemiş, teklifi Mustafa Kemal Paşa tarafından olumlu karşılanmıştır. ${ }^{86}$

Cumhurbaşkanının talimatıyla İran'ın son notasına, 17 Aralık'ta Tevfik Rüştü Bey imzalı bir notayla yanıt verilmiştir. Bu notada, Cemiyet-i

${ }^{84}$ A.g.e., s. 195-196 Hüsrev Bey bu görüşmede Fevzi Paşa'nın; İranlılar'a taviz olarak Şemdinan - Gevar hattının doğusunda İran'a doğru uzanan topraklarda ya da başka birkaç yerde Türkiye'nin alacağına karşılık aynı miktarda arazi verilebileceğini söylediğini yazmaktadır.

${ }^{85}$ A.g.e., s. 198-199

${ }^{86}$ A.g.e., s. 201 
Akvam'a üye olmayan Türkiye'nin böyle bir hakemlik başvurusu yapamayacağı, İran'ın olası bir başvurusunun ise "şikayet mahiyetinde" addedileceği, üstelik İran ile mevcut anlaşmalarda buna ait bir karar olmadığı, iki tarafın iyi niyetlerini gösteren mübadele kararından (karşılıklı verilecek topraklar kastediliyor) feragat için de ortada bir neden olmadığ 1 belirtilmiş, Dışişleri Bakanı'nın Tahran'a gelme isteği iletilmiştir. ${ }^{87}$

İstek İran tarafindan uygun görülmüş ve Tevfik Rüştü Bey, 9 Ocak 1932'de, aralarında İş Bankası Genel Müdürü Mahmut Celal (BAYAR) Bey'in de bulunduğu bir heyetle Türkiye'den ayrılmıştır. 17 Ocak'ta Tahran'a varan heyette, Mahmut Celal Bey'in de bulunması, ziyaretin sinır anlaşması dışında, başta ticari konular olmak üzere genel anlamda Türk-İran ilişkilerini masaya yatırma amaçlı olduğu izlenimini uyandırmıştır.

Tevfik Rüştü Bey başkanlığındaki Türk heyeti ile Furugi Han başkanlığındaki İran heyetinin yapmış olduğu görüşmeler, İran heyetinin bir nokta üzerindeki ısrarı dışında olumlu geçmiştir. İran heyeti, ileride Türkiye ile herhangi bir ihtilâfta bu yerin Türkiye için önemli bir savunma noktası oluşturacağından çekinmişlerdir. Tevfik Rüştü Bey, bu noktayla ilgili olarak Şah'ın hakemliğini Türk Hükûmeti adına kabul ettiğini bildirince, Şah'a konuyu iletmek üzere bir subay görevlendirilmiş, Şah da şu yanıtı vermiştir: "Meseleyi bu noktadan düşünmeyiniz, Türkiye ile Iran, hiç bir vakit müsellâh bir ihtilâfa gitmeyecektir." 88

Böylece son pürüz de Şah'ın devreye girmesiyle Türkiye lehine çözümlenmiş ve 23 Ocak 1932'de Türk-İran sınır anlaşması imzalanmıştır. Buna göre Ağrı Dağı'nın tamamı Türkiye'ye geçecek, Van civarındaki Kotur arazisi İran'a bırakılacaktır. Yapılan anlaşma, 18 Haziran'da TBMM'nin onayına sunulmuştur.

Sınırla ilgili olarak yapılan bu anlaşma meclisin onayına sunulurken, gerekçesi şöyle açıklanmıştır: "Bu itilâfname komşu devletle aramızda yegâne muallâk mesele olarak kalan hudut işini kati şekilde halleylemektedir. Şimdiye kadar Türkiye - Iran hududunda bazı mintakalar münaziünfih olmak dolaylstyla sükûnet ve asayişin tamamen takriri kabil olamiyordu. Bundan maada son senelerde tahaddüs eden şakavet hâdiseleri,

${ }^{87}$ Konunun ayrıntıları için bkz. a.g.e., s. 202-205

${ }^{88}$ TBMMZC, Devre: 4, Cilt: 9, İctima: 1, 65. İnikat, (18.06.1932), s. 163. (Tevfik Rüştü Bey'in 23 Ocak 1932 anlaşmasıyla ilgili olarak mecliste yapmış olduğı konuşma) Çetinsaya ‘ya göre Şah'1n yanıtı şu şekildedir: “Beni anlamıyorsunuz. Önemli olan şu ya da bu tepe değil, Türkiye ile olan problemlerimizin bir an önce ve ilelebed çözümlenmesidir. İki ülke arasında geçmişten gelen ve daima düşmanlarımızın işine yarayan uyuşmazlıklar son bulmalı ve Türkiye ile İan arasında karşılıklı çıkarlarımıza dayalı samimi bir dostluk kurulmalı. Eğer biz birleşir ve ittifak edersek kimseden korkmam." Çetinsaya, a.g.m., s. 167 
A ̆grı Dă̆ı mıntıkasında bazı arazinin bize verilmesi ve buna mukabil Iran'a arzî tevziatta bulunulmass sureti ile hududun tashihini icap ettirmekte olduğundan bu meselenin halli İran Hükûmetine teklif edilmiştir. Talebimiz hüsnü telâkki edilerek Tahranda müzakerata başlanmış ve neticede bu gün [30 Nisan] Meclisi Âlinin huzuruna arzedilen bu itilâfnamenin aktine muvaffakiyet hâsll olmuştur.

İtilâfname mucibince, Büyük erkânıharbiyemizce hududumuz dahilinde bulunması arzu edilen arazi bize verilmekte, buna mukabil Iran'a bir kisım arazi terkedilmektedir. Her veçhile menafiimize muvafik olan ve komşu Iran devleti ile hars ve Iktisat vadisinde de teşriki mesai suretiyle münasebatımızın daha ziyade takviyesine hizmet edecek olan bu itilâfname ile Türkiye ve Iran hudut muhafaza karakollarının Borolan Gölü membaları sularlyla mezkûr gölün muhitinde kâin çayırlardan ve Salep, Kozlu ve Yukar Yarımkaya membalar sularından müştereken istifade edeceklerine dair olarak tarafeyn arasında teati edilen ve itilâfnamenin cüzü mütemmimini teşkil eden mektup ahkâmının bir an evvel tasdiki Türkiye Büyük Millet Meclisinin yüksek reyine muallâktır., 89

Anlaşmayla ilgili olarak mecliste yapılan görüşmelerde söz alan Kocaeli milletvekili Sırrı Bey, Berlin Anlaşması ile İran Hükûmetine Kotur ve civarının verildiğini hatırlatmış, iki ülke arasında yıllardır süregelen sorunun çözüme ulaşmasından duyduğu mutluluğu dile getirmiş, fakat milletvekilleri olarak sınırın ne dereceye kadar Türkiye'nin emellerine uygun olduğunun anlaşılması için kendilerine bir kroki verilmesi gerektiğininin altını çizerek bunun yapılmadığını, her şeye rağmen bu konuda Genelkurmay'a güvendiklerini belirtmiştir. ${ }^{90}$

İki ülke arasında belirlenen yeni sınırlar, anlaşmanın ilk maddesinde ayrıntılı olarak belirtilmiştir. ${ }^{91}$ İkinci maddeye göre, ilk maddeyle belirlenen

${ }^{89}$ TBMMZC, Devre: 4, Cilt: 9, İctima: 1, 65. İnikat, (18.06.1932), S.say1s1: 198, s. 1

${ }^{90}$ Gös. yer, s. 163-164

${ }^{91}$ Gös. yer, s.4-6. Madde şöyledir: "Türkiye ile Iran arasındaki hudut Aras Nehri ile Karasu Irmağı'nın telâki noktasında Iran arazisinde kâin 1 numaralı hudut taşından başlar. Badehu Karasu Irmağı'nın talveg hattını Borolan gölüne kadar takip eder. Oradan Karasu membalarını 100 metre cenubu şarkisindeki tepeye kadar bir hatt müstakim halinde gider; mezkûr tepenin şark ve şimal cihetlerinden geçerek tepeyi Iran'a birakır. Müteakiben hat şimali garbiye doğru daha ziyade meylederek Karasu membalarının hemen üzerindeki Borolan kayalıklarına vâsıl olur. Hudut hattı 2 numaralı taştan sonra 3 numaralı taş ile Küçük Ağrı istikametinde 4, 5, 6, 7 ve 8 numaralı taşlardan geçerek Borolan Gölü'nün en şimalî sahiline hattı müstakim üzere 16.600 metre ve Küçük Ağrı dağının en yüksek noktasına 6.400 metre mesafede kâin bulunan 9 numaralı taşa kadar bir hattı müstakim takip eder. Badehu Bilidjan - Şeyhbabo yolunu 1700 metrelik bir mesafenin sonuna kadar mütevaziyen takip eder ve bu noktadan ilerleyerek Todjik Tepe'nin 100 metre, cenubu şarkisine vâsıl olur 
ve mezkûr tepeyi Türkiye'ye bırakır. Müteakiben hat cenubu garbiye doğru meylederek Todjik köyünün 150 metre şarkından geçer ve bu köyü Türkiye'ye birakır ve ayni istikamette devam ederek Şeyhbabo'nun 3000 metre şarkında kâin Top mevkiinin 100 metre garbinden geçerek Top'u Iran'a birakır. Oradan hat Şeyhbabo'nun 2500 metre cenubu şarkisinde kâin tepeye doğru teveccüh eder. Mezkûr tepenin zirvesinden geçerek Hasanağa köyünün 1300 metre şarkında bulunan tepeye kadar cenubu garbiye doğru gider, ve bu sonuncu tepenin zirvesinden geçer; badehu hat Hasanağa köyünün 800 metre cenubunda kâin tepeye kadar garbe teveccüh eder ve bu tepenin zirvesinden geçer. Oradan 500 metre cenubu garbide kâin tepenin zirvesinden geçerek cenuba doğru 1500 metre sırtı iner ve Salepin cenubu şarkisinde 2000 metrede kâin bir noktaya kadar gider, sonra 1948 rakıml tepenin 800 ve 1000 metre şimalinde bulunan başlıca iki irtifain arasındaki boyundan geçer.

Badehu hat, hattı balâdan 1948 rakımlı tepeye kadar giderek üzerinden geçer; oradan hat Aybey Dağları tepelerinin taksimi miyah hattın cenuba doğru Yarım Kaya - Guijo yolu dirseğinin 700 metre şimali garbisinde bulunan mezkûr dağların cenup tepesine kadar takip eder. Mevzubahis dirsek bu yolun üzerinde Yarım Kayanın 3500 metre şimali şarkisinde ve Guijonun 6300 metre cenubu garbisinde kâindir. Oradan, hat yukarı Yarım Kayanın 200 metre şimalinde bulunan dört yol ă̆zına kadar Yarım Kaya - Guijo yolunun 200 metre garbinden bu yola muvazi olarak devam eder ve mezkûr dört yol ăgzını İrana bırakır. Oradan hat Yarım - Kaya - Bulakbaşı yolunun üzerinde Yarım Kayanın 600 metre garbinde kâin bir noktaya kadar garbe doğru iner; badehu bataklık sahilinin en şimali noktasina kadar cenuba doğru inerek bu noktadan hat bataklığın ortasına teveccüh eder ve Tchoukour - Rech 'in 500 metre şimalindeki cenup sahiline kadar bataklı̆̆ı ortasını takip eder. Oradan hat garbe doğru döner ve 1668 rakıml tepenin zirvesine vâsll olur. Tchoukour - Reche ve Cheytan Abad Iran'a, Guirberan ise Türkiye'ye kalır.

Iran köyü olan Cheytan Abad ile Türk köyü olan Guirberan arasında kâin bu noktadan itibaren hudut Bazirgan garbinde Guirberan tepesinin sırtını çıkar ve Gurdji Boulak, Nazik, Kara Koymaz Türk köyleri ile Bazirgan, Kedjot, Bach Kend, Marokeumou Iran köyleri arasında taksimi meyah hattını takip eder, badehu Marokeumou ve Tawla ( Türk) arasındaki boyunu geçer ve Kasorlüo, Chekh Asker harabelerini Iran'a terkederek Hocadağ kayalıklarına vâsıl olur. Kanlı Baba'nın Zindo-Dachy ve Akdağ zirvelerinden geçer. Djevzar köyünü Irana birakarak ve Akdağ ve Kalender zirvelerinden geçerek Nifto, Salmanabad ve Pir Ahmet Iran köyleri tarlaları ile Deuchourma Türk köyünün tarlalarını birbirinden ayırdıktan sonra Bayazıt ve Avadjik arasında daima taksimi meyah hattın takip ederek Khezine Guedoka vâsıl olur. Khezine Guedok'tan hudut, Klzllkaya köyünü Türkiye'ye, Sivmagül Köyü ile Korugül Gölü'nü Irran'a bırakarak Karagüney tepesinden geçer, Eğriçay Irmağını Akdağ'dan kateder, Nado Köyü'nü Iran'a, Eğriçay Köyü'nü de Türkiye'ye bırakır, Kızılziyaret Tepeleri'ne vâsıl olur ve Akdağ Hangedik boyunlarından, Sarıçimen Dağları'ndan, Domanlı'nın garp zirvesinden, Karaburga boyunundan geçer; Şeyh Selo köylerini İran arazisinde bırakarak Navur Tepesini aşarak, Yekmala köyünü İran arazisinde bırakarak Riçkandan, Davra ve Akhurik, arasındaki tepelerden Guevra Begzadan, Gueveri Makhine ve Hıdırbaba'dan geçer. 
Hıdırbaba'dan itibaren hudut hattı Dasena Gölünün 2000 metre şarkından geçerek cenup istikametinde 8000 rakıml tepeye kadar taksimi miyah hattın takip eder; 1000 metre daha tepeler üzerinden ayni istikamette devam eder, badehu cenubu şarkiye meyleder ve bu yeni istikamette 600 metrede tepeleri takip eder; bundan sonra 500 metre mesafede kâin bir tepenin zirvesine kadar yeniden cenuba döner, 250 metre şimali şarkî istikametinde kâin Mümtet Tepeyi Iran'a terkeder. Oradan 500 metre cenubu şarkide kâin yüksekliğin zirvesine kadar hattı balâyı takip eder, badehu Heratlısu ile Kotur Çay'ın birleştikleri noktaya kadar cenubu garbiye doğru iner. Sonra hat bu mevkie 800 metre mesafede kâin zirveye kadar cenuba doğru yamacı çıkar ve oradan daima cenup istikametinde Kani-Reche vadisine iner, bu vadinin talveg hattın 700 metre garbe doğru, sonra 500 metrede cenuba doğru takip eder; badehu doğrudan doğruya cenupta kâin Molla Memed Dağı'na doğru yükselen uzun strtı çıkar, Molla Memed Dă̆ı'nı ikiye ayırır, Molla Memed Dă̆ı'na 250 metre mesafede ve hududun 250 metre şarkındaki irtifaı Iran'a birakır.

Molla Memed Dă̆g'ndan itibaren hat 800 metre bir mesafe üzerinde Kiçla'nın 200 metre şarkında yol üzerinde kâin bir noktaya kadar sırtı takip eder ve Kiçla'yı Türkiye'ye birakır. Sonra hudut yolun dirseğinin 1750 metre cenubunda kâin tepeye kadar cenubu şarkiye doğru taksimi miyah hattın takip eder. Bu noktadan hat, tepeler üzerinden oraya 2200 metre mesafede derenin içinden geçen yolun üzerinde kâin noktaya kadar cenuba doğru iner; bu noktadan 300 metrelik bir mesafe üzerinde cenuba doğru yamacı çıkar, cenubu garbiye doğru sirta vâsıl olur ve buraya 500 metre mesafede kâin bir tepeye kadar gider. Badehu oradan 900 metre mesafede Tarsava, Tehelik, Achaga yolunun dereyi geçtiği noktaya kadar tepeler istikametini takiben cenuba doğru iner, bu derenin talveg hattın 500 metre imtidadınca garbe doğru takip eder, sonra sirtlardan geçerek buraya 1700 metre mesafede kâin 8200 rakımlı tepeye kadar çıkar. Badehu hat Kuç Dağı'na kadar cenubu şarkiye doğru tepeleri takip eder, Kuç Dağı'ndan itibaren Kach Koul boynunu geçerek Sourawou dağına kadar hattı balâyı takip eder. Sourawou dağlarından, hudut mütemadiyen taksimi miyah hattını takiben Barouch - Khoran dan geçer ( Barouch Khoran köyünü Iran arazisinde bırakır ) Haravil dă̆ını, Khana Sour boynunu, Belâko yu, Sarı Tehitchek i, ( Kalık köyünü Iran arazisinde birakarak) Kepper i, Sorian i, Berhebine dağını, Sultani boynunu, Barazivan dă̆ını, Perikhan i, Keifarouk u, Maidan ve Kotoul Dagh i takip eder.

Hudut hattı Kotoul dağının 2869 rakımlı tepesinden hareketle cenubu şarkiye doğru hattı balâyi takiben Bajirge'nin 1600 metre şarkında Baradost ırmağının üzerinde kâin bir noktaya kadar gider, 1890 rakıml irtifaın cenuba doğru devamını teşkil eden sırtı İran'a terkeder (binaenaleyh hattı hudut dereden geçer). Oradan hat cenubu şarkiye doğru gider ve CXLVIII ve CXLVII numaralı hudut taşlarının bulunduğu tepeden geçerek şarkı cenubiye doğru döner ve tepeye 450 metre mesafede bulunan Ekmalouk ırmağına kadar gider. Badehu 2300 rakıml tepenin 800 metre garbinde kâin irtifaa kadar Ekmalouk deresi boyunca yükselir. Oradan 2530 rakaml tepeye kadar hattı battya takip eder. Badehu Alosan'in 1500 metre garbinde kâin bir noktaya kadar, 2500 metre imtidadınca cenubu garbiye doğru hattı balâyı takip eder. Alosan Iran'a kalır. Oradan hat takriben 2500 metre mesafede bulunan sırtın dirseğine kadar cenup istikametinde bu sırtı takip eder. Badehu Alader Dağl'na kadar daima sırtları takip ederek şarka doğru döner. Sonra, Paqui'den gelen dere ile Berdereche 
sınır hattını arazi üzerinde belirlemek için bir "tahdit komisyonu" olușturulacaktır. Bu komisyon, ikisi Türkiye Hükümeti, ikisi de İran Hükûmeti tarafından atanacak dört üyeden oluşacaktır. Komisyon, 1932 Haziran ayı içesinde toplanacak, yapılacak harcamalar, Türkiye ile İran arasında bölüşülecektir.

Yine aynı maddeye göre taraflar, komisyonun görevini yerine getirebilmesi için gereken şeyleri karşılamak için komisyona yardım edeceklerini; komisyon tarafından vazolunacak nirengi noktalarını, hudut işaretlerini, kazıkları ve sınır taşlarını koruyacaklarını taahhüt ediyorlardı. Hudut taşları birinden diğeri görülebilecek surette vazedilecek ve üzerlerine numara konulacaktır.

Üçüncü maddede ise itilâfnamenin onaylanması sonrasında süratle Ankara'da teati edileceği karara bağlanmıştır. Bu arada ikinci madde uyarınca çalışmalarına başlayan sınır tespit komisyonu, çalışmalarını 1934'te tamamlamıştır. ${ }^{92}$

Fakat 1936'ya gelindiğinde, 1932 Anlaşması'nın Mazbişo, Paki ve Eli bölgelerine yönelik hükümlerinin, hattın çiziminde kullanılan haritaya uymadığ1 görülmüş ve bu konuda Bakanlar Kurulu kararıyla, Genelkurmay'ın görüşleri doğrultusunda bir sınır düzenlemesi yapılması için 30 Nisan'da Tahran Büyükelçiliğine yetki verilmiştir ${ }^{93}$ Bu yetkiye dayanarak harekete geçen Tahran Büyükelçisi Enis Akaygen'in İranlı

Çay'ın birleştikleri noktanın 2400 metre şimalinde bulunan zirveye .kadar cenubu şarkiye doğru sırtlarl iner. Oradan hat, yukarıda zikrolunan birleşme noktasına kadar cenuba doğru iner.

Sonra Berdereche Çay'in talveg hattını bu çayın Garachine Dağı'nın 1000 metre garbinden inen dere ile birleştiği noktaya kadar takip eder. Hat cenuba doğru 1600 metre imtidadınca bu derenin talveg hattın takip eder; sonra Garachine Dă̆ı'nın garp zirvesine kadar cenubu şarkiye doğru giden sırtı çıkar. Eli ve Paqui mevkileri Türkiye'ye, Maz Bicho mevkii Irana kalır.

Garachine Dă̆'dan itibaren hudut Kouna Hoter, Zinwi Taboutan, Helane, Col Kelechineden geçer ve Delamper dağının zirvesine çıkarak Türkiye - Irak hududundaki 99 numaralı hudut taşına vâsıl olur. 1 numaralı hudut taşından Irak hududundaki 99 numaralı taşa kadar hudut hattını doğru bir tarzda çizilmesi ve tafsilâtı için, Yüksek Akitlerin murahhaslarl tarafindan tasdik ve mütehassislarl tarafindan imza olunan ve bu itilâf nameye merbut bulunan (1:84000 ve 1 : 50000 mikyasinda) XVIII - XIX - XX - XXI - XXII - XXII a XXIII - XXIV ve XXV numaralı 9 adet harita ile bir adet (calque) a müracaat edilecektir. (Mevki isimlerinin imlâsı yukarıda zikrolunan haritalar ve " calque " daki isimlerin imlâsına mutabık olacaktır.)

92 Çetinsaya, a.g.m., s.168

${ }^{93}$ BCA, Tarih:30/04/1936, Dosya:4530, Fon Kodu:30..18.01.02, Yer No: 64.36..15. (İranlılar'la huduttaki Mazbişo mıntıkasından doğan ihtilaf hakkında.) 
yetkililerle yaptığı bir dizi görüşme sonuç vermiş ve 27 Mayıs 1937'de İran Hariciye Veziri İnayetullah Samiy ile Türk büyükelçisi Enis Akaygen arasında 1932 Anlaşması'nı düzenleyen bir anlaşma imzalanmıştır ${ }^{94}$. Söz konusu anlaşma, 17 Haziran 1938'de Meclis'te onaylanmıştır. ${ }^{95}$

\section{Sonuç}

16.yy. da Osmanlı Devleti ile Safeviler arasında başlayıp, yaklaşık dört yüz yıllık bir süreç izleyerek cumhuriyetin ilk yıllarına kadar uzanan sınır anlaşmazlıkları, 23 Ocak 1932'de imzalanan Türk-İran Sınır Anlaşması ile çözüme ulaştırılmıştır. Sınır konusunun çözümü, iki ülke arasında diğer konularda da işbirliği kapılarını ardına kadar aralamıştır.

Nitekim söz konusu anlaşmayı, 5 Kasım 1932'de imzalanan iki ayrı anlaşma, "Türkiye-İran Dostluk Anlaşması" ve "Güvenlik, Tarafsızlık ve Ekonomik İşbirliği Anlaşması" izlemiştir. Rıza Şah'ın Haziran 1934'te Türkiye'ye yapmış olduğu yaklaşık 1 aylık gezi ise ilişkileri oldukça güçlendirmiştir. Rıza Şah'ın ilk ve tek yurt dışı ziyaretinin Türkiye'ye yapılmış olan bu ziyaret olması, Rıza Şah'ın hem Atatürk'ten hem de çağdaşlığa ulaşmaya çalışan Türkiye'den ne kadar etkilendiğini de göstermektedir. $\mathrm{Bu}$ ziyaret, bölgesel barışa katkıda bulunan Sadabad Paktı'na giden yolu da açmış, saldırmazlık esasına dayanan bu pakt ile her iki ülke de Ortadoğu'ya egemen olmaya çalışan güçlere karşı bir güçbirliği içerisine girerek, bölgede siyasi istikrarı korumaya yönelik önemli bir adım atmışlardır.

941937 yılı içerisinde iki ülke arasındaki ilişkilerde yoğunluğun arttığı ve bir dizi anlaşmanın yapıldığ 1 görülmektedir. Bunlar arasında, "İkamet Mukavelenamesi”,"Hava-i Seyrüsefer Mukavelenamesi", "Müzaheret-i Adliye Mukavelenamesi”, "Telefon ve Telgraf Anlaşması", "Suçluların İadesi Mukavelenamesi" ve "Baytari Mukavelename" sayılabilir. Bu anlaşmaların maddeleri için bkz. TBMMZC, Devre:5, Cilt:19, İctima:2, 72.İnikat, (07.06.1937), s.107-138.

95 TBMMZC, Devre:5, Cilt:22, İctima:3, 29.İnikat, (17.01.1938), s.148 Buna göre, 1932 Anlaşması'nın 1. maddesinin 8. fikrası değiştirilmiştir. Önceki anlaşmada ilgili fikrada “(...) Eli ve Paki Türkiye’ye, Mazbişo mahalli İran'a kalır.” denilirken, yapılan değişiklikle fikra, “(...) Eli ve Paki Türkiye’ye ve Mazbişo mevkiinin Paki'den gelen ırmağın şarkında kalan kısmı Iran'a kalır.” şekline dönüştürülmüştür. 


\section{KAYNAKÇA}

\section{Arşiv Kaynakları}

BCA, Tarih:03/09/1929, Dosya:9236, Fon Kodu:30..10.0.0, Yer No: 112.753..14. (Ağrı Dağı eşkıyası hakkında Bayezit vilayetinden alınan şifre.)

BCA, Tarih:30/04/1936, Dosya:4530, Fon Kodu:30..18.01.02, Yer No: 64.36..15. (İranlılar'la huduttaki Mazbişo mıntıkasından doğan ihtilaf hakkında.)

\section{Resmi ve Süreli Yayınlar}

TBMM Zabit Ceridesi

Milliyet

Cumhuriyet

Vakit

Hakimiyet-i Milliye

\section{İnceleme Yapıtlar (Kitaplar ve Makaleler)}

Abbasl1, Mirza, "Safevilerin Kökenine Dair", Belleten, C:XL, (Nisan 1976), S:158'den ayrıbasım, TTK Basımevi, Ankara, 1976, s. 299-300.

Abdurrahman Şeref, Tarih-i Devlet-i Osmaniyye, İstanbul, 1312/1894, C.II.

Aykun, İbrahim, Erzurum Konferansı (1843-1847) ve Osmanlı-İran Hudut Anlaşması, Atatürk Üniversitesi, Sosyal Bilimler Enstitüsü (Yayımlanmamış doktora tezi), Erzurum, 1995.

Cevdet Paşa, Tarih-i Cevdet, Matbaa-i Osmaniye, İstanbul, 1309/1892, C.II

Çay, Abdulhaluk, Her Yönüyle Kürt Dosyası, Ankara, 1994.

Çetinsaya, Gökhan, "Milli Mücadele'den Cumhuriyet'e Türk-İran İlişkileri 19191925”, Atatürk Araştırma Merkezi Dergisi, Sayı 48, Cilt: XVI, (Kasım 2000), s. 769-796.

“Atatürk Dönemi Türkiye-İran İlişkileri 1926-1938”, Avrasya Dosyası, 5/3, (Sonbahar 1999), s.148-175.

Efendizade, Oktay, Safevi Devleti’nin Kuruluşunda Azeri Türklerinin Rolüne Dair, XI.Türk Tarih Kongresi'nden ayrıbasım, TTK Yayınevi, Ankara, 1994, S. $813-820$

Erim, Nihat, “Türkiye Cumhuriyeti’nin Kuzeydoğu ve Doğu Sinırları”, Ankara Üniversitesi Hukuk Fakültesi Mecmuası, Y1l:1952, C.9, S.1-2, s.1-26. 
Eser, Alâattin, "Bir Hudûdun Anatomisi: Seyahatname-i Hudûd", Tarih ve Toplum, (Mart 1988), C:9, S:51, s.57-61 Genekurmay Belgelerinde Kürt İsyanları, Kaynak Yayınları, İstanbul, 1992.

Gerede, Hüsrev, Siyasi Hatıralarım I - İran, Vakit Basımevi, İstanbul 1952.

Hammer, Joseph V., Osmanlı Tarihi, C.II, II.Baskı, İstanbul, 2005.

HİNZ Walter, Uzun Hasan ve Şeyh Cüneyd XV. Yüzyılda İran'ın Millî Bir Devlet Haline Yükselişi, TTK Yay. Ankara, 1992.

Hoca Saadettin, Tacü’t Tevarih, T.C. Kültür Bakanlığı Yayınevi, Ankara, 1979, C.II

İlseven Ragıp, Türk-İran Hudut İhtilafının Tarihçesi, Dışişleri Bakanlığı Basımevi, Ankara, 1935.

Kevserani Vecih , Osmanlı ve Safevilerde Din - Devlet İlişkisi, Denge Yay., İstanbul 1992.

Koloğlu Orhan, “Osmanlı’nın İran İlișkileri”, Popüler Tarih, S.57, (Mayıs 2005) s.71-73.

Küçük Cevdet, “İran-Irak Hududunu Belirleyen 1913 Tarihli İstanbul Protokolü”, İstanbul Üniversitesi Edebiyat Fakültesi Dergisi, (Doğumunun 100. Y1lında Atatürk'e Armağan), İstanbul, 1981, s.243-268.

Mehmed Hurşid Paşa, Seyâhatnâme-i Hudûd, Simurg Yay., İstanbul, 1997

Mustafa Nuri Paşa, Netayic Ül-Vukuat - Kurumları ve Örgütleriyle Osmanlı Tarihi, TTK yay., Çev: Neşet ÇAĞATAY, Ankara, 1992.

Metin Barış, Birinci Dünya Savaşı'nda İran Coğrafyasında Etnik, Dini ve Siyasi Nüfuz Mücadeleleri, (Yayımlanmamış doktora tezi), Ankara, 2007. Muahedat Mecmuası, TTK yay., Ankara, 2008, C.II-III.

Mumcu Uğur, Kürt-İslam Ayaklanması (1919-1925), Tekin Yayınları, Ankara, 1995.

Nadi Yunus, “Komşumuz İran”, Cumhuriyet, ( 10 Ağustos 1920).

Ocak Ahmet Yaşar, "Osmanlı Kaynaklarında ve ModernTürk Tarihçiliğinde Osmanlı-Safevî Münasebetleri (XVI-XVII. Yüzyıllar)”, Belleten, C:LXVI, (Ağustos 2002), S:246'dan ayrıbasım, TTK Basımevi, Ankara, 2003, s.503516

Saruhan Zeki, Kurtuluş Savaşı Günlüğü IV: Sakarya Savaşı'ndan Lozan'ın Açılışına, TTK yay., Ankara, 1996.

Sonyel Salahi, Türk Kurtuluş Savaşı ve Dış Politika I, TTK yay., Ankara, 1995. 
Sümer Faruk, Safevi Devletinin Kuruluşu ve Gelişmesinde Anadolu Türkleri’nin Rolü, TTK Basımevi, Ankara, 1992.

Şimşir Bilal, Bizim Diplomatlar, Bilgi Yayınevi, İstanbul, 1996.

Türkiye Cumhuriyeti'nde Ayaklanmalar, Gnkur.Harp Tarihi Başkanlı̆̆ yay.,Ank., 1972.

Uzunçarșılı İsmail Hakkı, Osmanlı Tarihi, TTK yay., Ankara, 1983, C.II-III 